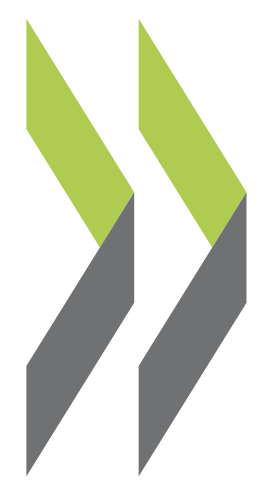

OECD Economics Department Working Papers No. 841

Enhancing the CostEffectiveness of Climate Change Mitigation Policies Stéphanie Jamet

in Sweden 
Organisation de Coopération et de Développement Économiques

Organisation for Economic Co-operation and Development

09-Feb-2011

ECONOMICS DEPARTMENT

English, French

ENHANCING THE COST-EFFECTIVENESS OF CLIMATE CHANGE MITIGATION POLICIES IN SWEDEN

ECONOMICS DEPARTMENT WORKING PAPER No. 841

By Stéphanie Jamet

All Economics Department Working papers are available through the OECD internet website at www.oecd.org/workingpapers 


\section{ABSTRACT/RÉSUMÉ}

\section{Enhancing the cost-effectiveness of climate change mitigation policies in Sweden}

Sweden has developed an extensive and sound policy framework to limit greenhouse gas emissions. It is now one of the OECD countries with the lowest greenhouse gas emissions per capita and it has successfully managed to decouple GDP growth from emissions growth. However, as Sweden has already significantly lowered its greenhouse gas emissions, the cost of reducing them further could be very high, making it urgent to improve the cost-effectiveness of Sweden's climate change policies. A strategy to enhance the cost-effectiveness of this policy framework would include: i) reducing differences in carbon prices between sectors and increasing even further the role of market-based instruments; ii) limiting overlap between targets and policies; iii) raising Sweden's participation in greenhouse gas emission reductions abroad; and iv) improving the assessments of the policy framework. This Working Paper relates to the 2011 OECD Economic Survey of Sweden (www.oecd.org/eco/surveys/Sweden).

JEL classification: Q48 ; Q54 ; Q58

Keywords: Sweden, climate change; greenhouse gases emissions; climate change mitigation policy; carbon tax; green certificates; renewable energy

$* * * * *$

\section{Améliorer le rapport coût-efficacité des politiques d'atténuation du changement climatique en Suède}

La Suède s'est dotée d'un cadre d'action solide et très complet pour limiter ses émissions de gaz à effet de serre. Elle figure aujourd'hui parmi les pays de l'OCDE qui affichent les plus faibles taux d'émission de gaz à effet de serre par habitant et a réussi à découpler la croissance de son PIB de celle de ses émissions. Toutefois, sachant que les émissions de gaz à effet de serre ont déjà été sensiblement réduites, le coût de nouvelles réductions pourrait s'avérer très élevé, d'où la nécessité d'améliorer d'urgence le rapport coûtefficacité des politiques de la Suède en matière de changement climatique. La stratégie envisagée pour améliorer l'efficacité-coût du cadre d'action pourrait consister à : i) réduire les différentiels de prix du carbone entre dans les différents secteurs et faire jouer encore davantage les instruments de marché ; ii) limiter les chevauchements entre objectifs et mesures; iii) accroître la participation de la Suède aux réductions des émissions de gaz à effet de serre à l'étranger; et iv) améliorer les évaluations du cadre d'action. Ce document de travail se rapporte à l'Étude économique de la Suède 2011 (www.oecd.org/eco/etudes/Suede).

Classification JEL: Q48 ; Q54 ; Q58

Mots-clefs : Suède, changement climatique ; émissions de gaz à effet de serre ; politiques d'atténuation du changement climatique ; taxe carbone ; certificats verts

\section{Copyright OECD 2010}

Application for permission to reproduce or translate all, or part of, this material should be made to: Head of Publications Service, OECD, 2 rue André-Pascal, 75775 Paris cedex 16, France. 


\section{TABLE OF CONTENTS}

\section{ENHANCING THE COST-EFFECTIVENESS OF CLIMATE CHANGE MITIGATION POLICIES IN

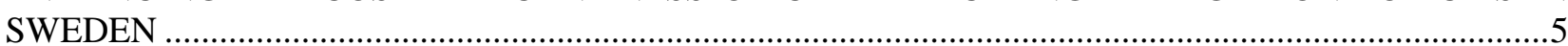

Sweden, a clean country with ambitious GHG emission reduction targets .............................................

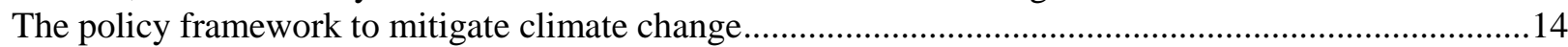

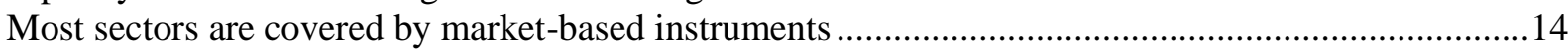

The carbon tax interacts with the energy tax and includes several exemptions ...................................16

The EU ETS should allow Sweden to finance emission reductions in other European countries .........18

The electricity certificate system has boosted the development of renewable energy but at a high cost 19

Other instruments complement the framework, some of them with low cost-effectiveness .................22

Overall, the policy framework has lead to significant GHG emission reductions but more could have

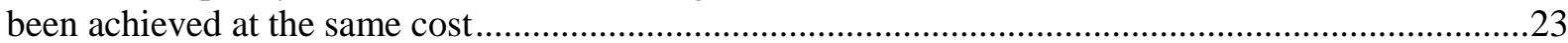

Moving forward: improving the cost-effectiveness of the policy framework ........................................24

Making the carbon price more uniform, more visible and even more central.....................................25

Raising the share of GHG emission reductions achieved in sectors covered by the EU ETS and outside

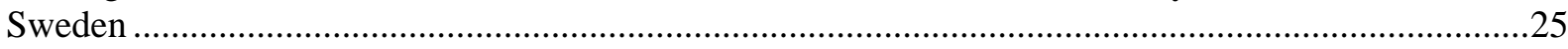

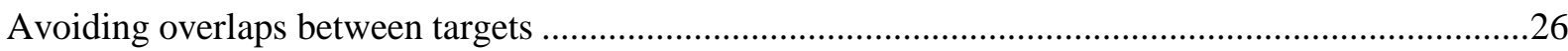

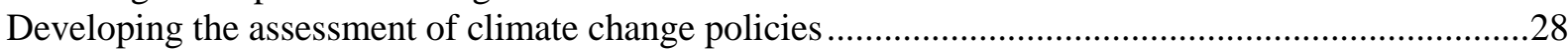

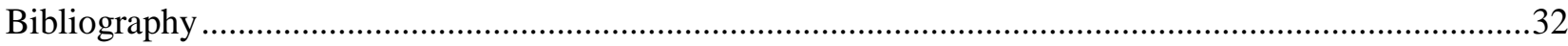

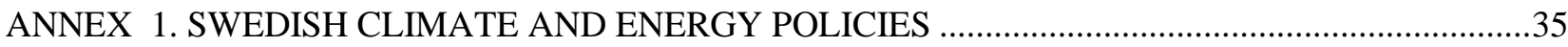

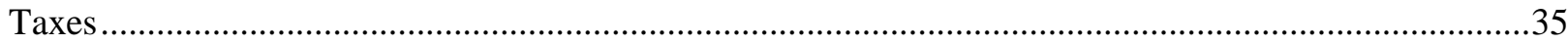

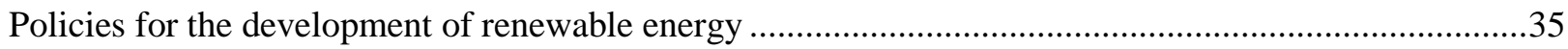

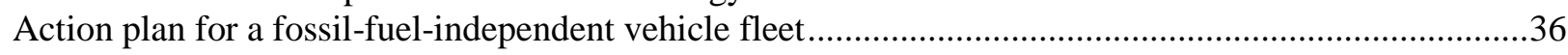

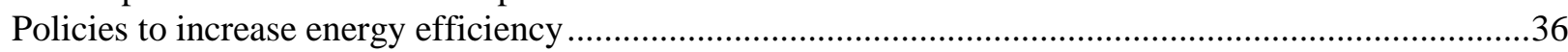

\section{Tables}

Table 1. Decomposition of GHG emissions in selected countries.........................................................12

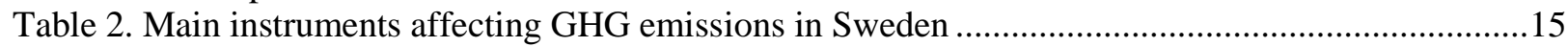

Table 3. GHG emission reduction projections over 1990-2020 in Sweden.............................................23

\section{Figures}

Figure 1. World emission trends by country/region

Figure 2. The gap between pledged targets and the trajectory towards the long-term goal of limiting the global temperature increase to $2 \mathrm{C}$.

Figure 3. GHG emissions in Annex I countries, trend and level ..........................................................10

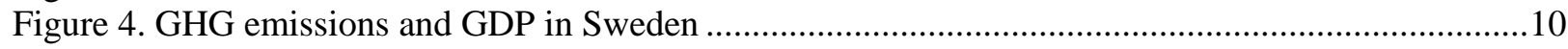

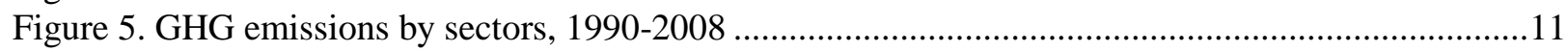

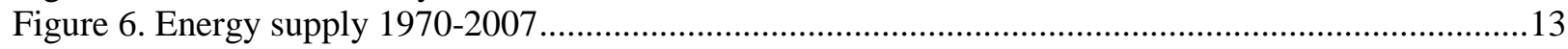

Figure 7. Share of renewable energy in total energy supply in Sweden and OECD ...............................13

Figure 8. Evolution of the general CO2 tax rate in Sweden ................................................................16

Figure 9. Implicit tax rates on CO2 in OECD countries and in Sweden ..............................................17 


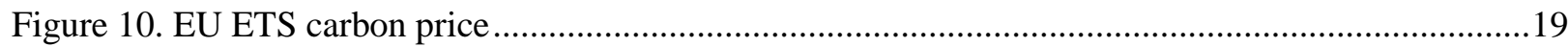

Figure 11. Average price of spot traded electricity certificates in the electricity certificate system .........21

Figure 12. Patents in renewable energy technologies, 1978-2005 ........................................................21

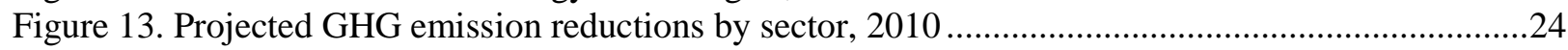

\section{Boxes}

Box 1. The political economy of climate change: some lessons from Sweden .......................................7

Box 2. Main national and international climate change mitigation targets applying to Sweden .................8

Box 3. Designing a cost-effective set of climate mitigation policy instruments.......................................14

Box 4. Summary of recommendations to enhance the cost-effectiveness of climate change policies in

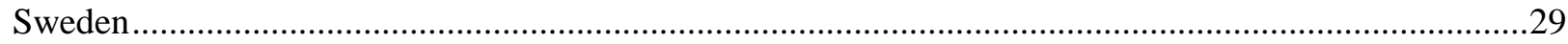




\title{
ENHANCING THE COST-EFFECTIVENESS OF CLIMATE CHANGE MITIGATION POLICIES IN SWEDEN
}

\author{
By Stéphanie Jamet ${ }^{1}$
}

The pace of the world's greenhouse gas (GHG) emissions into the atmosphere has picked up sharply since the mid-1990s, driven mainly by economic growth in developing countries (Figure 1). While the recent recession can be expected to reduce global emissions, the impact on the build-up of GHG concentration will be only temporary. Without any further policy action, GHG concentrations would continue to rise and the resulting increase in temperatures could be well over $2^{\circ} \mathrm{C}$ by 2050 . Wide economic and environmental uncertainties surround the expected damages from the business-as-usual (BAU) scenario but there is a significant probability of very large losses which justifies reducing global emissions to levels which ensure a "low" probability of extreme and irreversible damage from climate change.

\section{Figure 1. World emission trends by country/region}

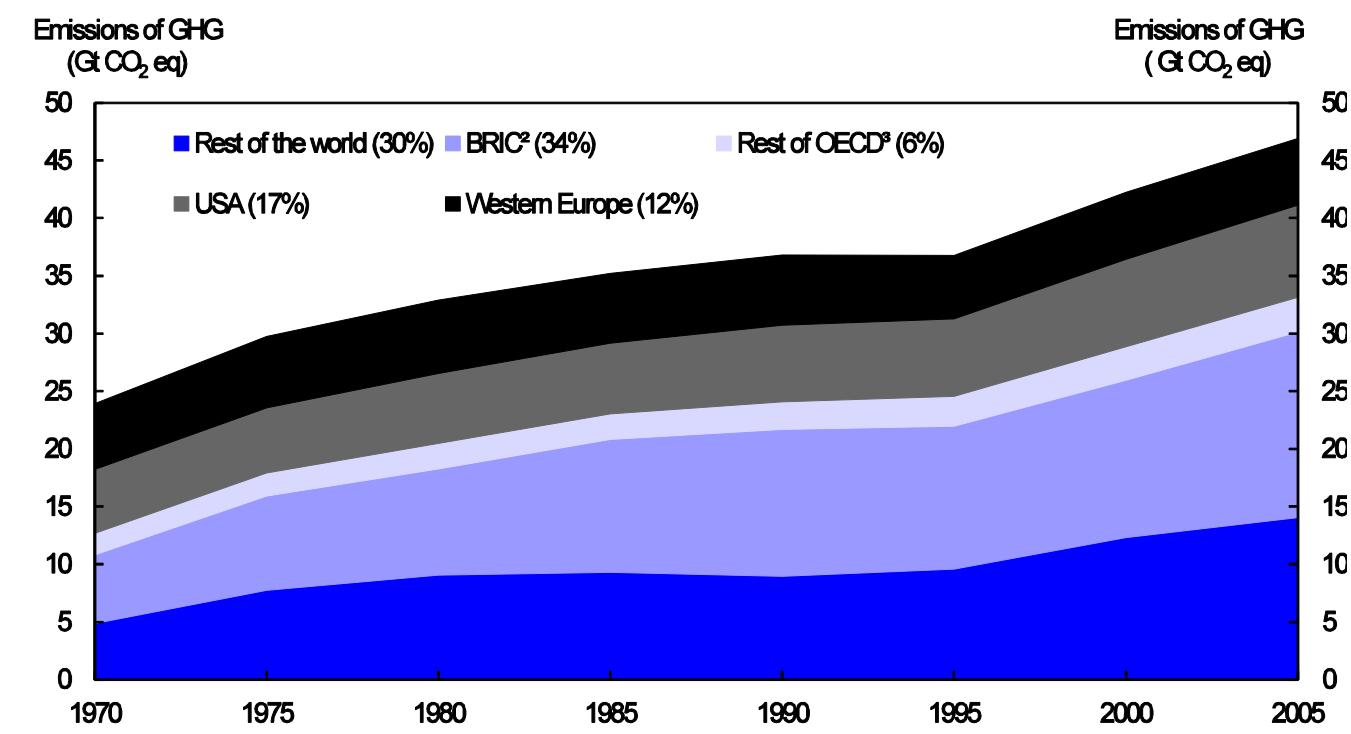

1. Including emissions from land use, land-use change and forestry. Number in brackets represents percentage share of total emissions in 2005.

2. Brazil, Russia, India and China.

3. Rest of OECD does not include Korea, Mexico and Turkey, which are aggregated in Rest of the world.

Source: OECD Environmental Outlook to 2030 (2008).

1. Senior Economist in the OECD Economics Department (Email: stephanie.jamet@oecd.org). This paper is based on work originally prepared for the 2010 Economic Survey of Sweden published on 20 January 2011 under the authority of the Economic and Development Review Committee (EDRC). The author wishes to thank Mattias Ankarhem, Nils-Axel Braathen, Fredrik Bystedt, Andrew Dean, Alain de Serres, Jane Ellis, Bob Ford, Vincent Koen, Paul O’Brien, and Eva Samakovlis for helpful comments as well as Thomas Chalaux for excellent statistical assistance and Pascal Halim for editing assistance. The author retains full responsibility for errors and omissions. 
At the Copenhagen Conference of parties (COP-15) in 2009 under the UN Framework Convention on Climate Change (UNFCCC), a number of developing and developed countries (more than 120 countries plus the European Union) have agreed that the increase in average global temperature needs to be kept below $2{ }^{\circ} \mathrm{C}$. According to IPCC estimates, limiting the temperature increase to $2^{\circ} \mathrm{C}$ would require stabilising GHG concentrations at 445-490 ppm $\mathrm{CO}_{2}$ eq and reducing $\mathrm{CO}_{2}$ emissions relative to 2000 by 50-85\% by 2050. As of May 2010, 42 Annex I countries ${ }^{1}$ had pledged quantified economy-wide emissions targets for 2020, and 36 non-Annex I countries had pledged mitigation actions (OECD, 2010a). However, OECD estimates show that the emission reductions embodied in these pledges are not sufficient to put emissions on a pathway limiting the average global temperature increase to $2^{\circ} \mathrm{C}$ (Figure 2).

Figure 2. The gap between pledged targets and the trajectory towards the long-term goal of limiting the global temperature increase to $2 \mathrm{C}$

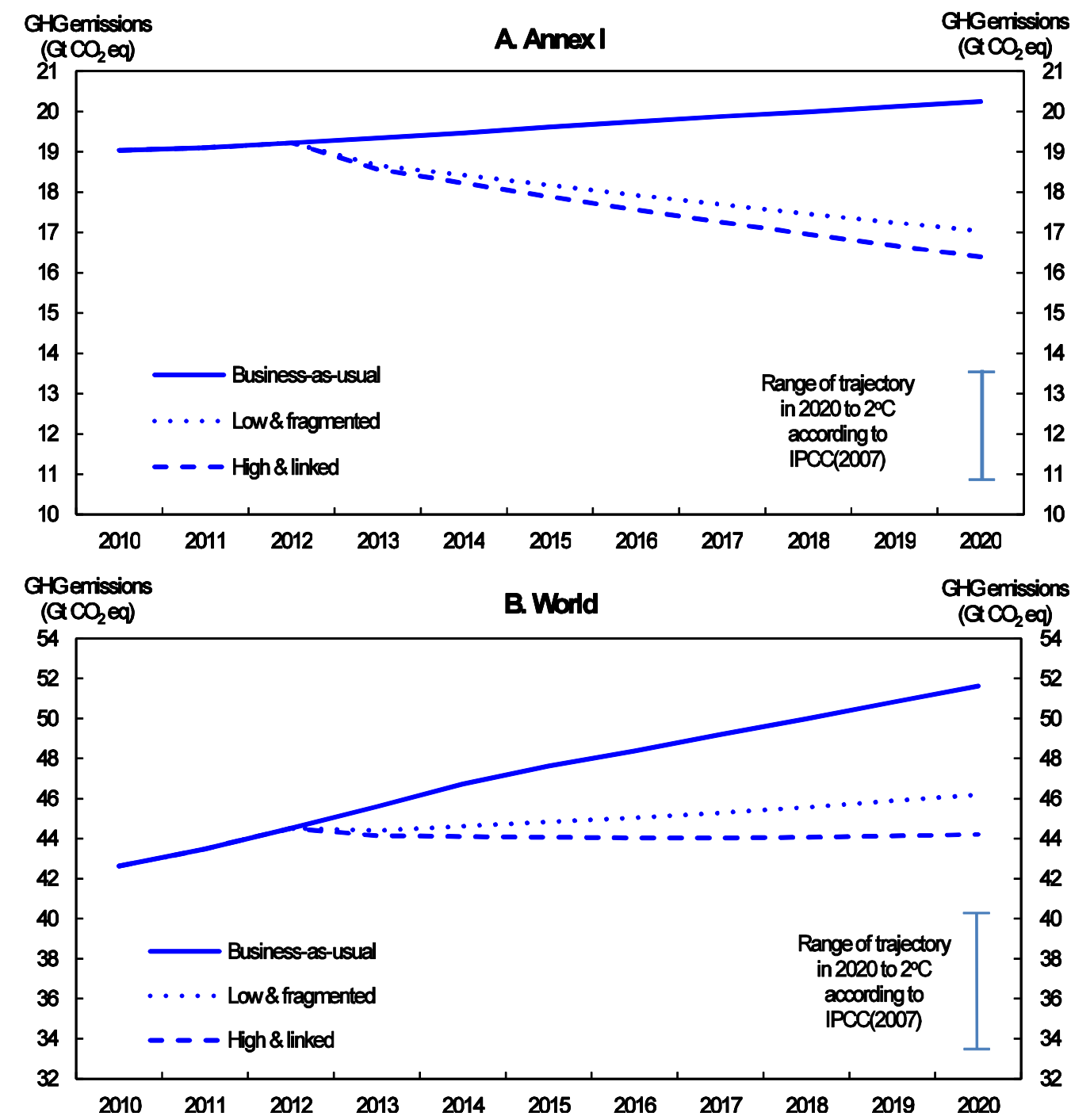

Note: The "Low \& Fragmented" scenario corresponds to all countries meeting the lower end of their pledged ranges, while the "High \& Linked" scenario corresponds to all countries meeting the higher end. The High \& Linked scenario assumes trading of emission permits between Annex I countries while the "Low \& Fragmented" scenario does not include trading. In both cases, the assumption is made that $20 \%$ of the required emission reductions in Annex I countries can be fulfilled through the use of international offsets.

Source: OECD (2010a). 
Sweden is strongly engaged in the efforts to tackle climate change. The country has already successfully reduced its GHG emissions and has adopted ambitious targets to lower them even further. Sweden has ratified the Kyoto protocol, is participating actively in EU climate policies and is willing to "take the lead" on these issues. Sweden's efforts and performance are all the more commendable as the incentives for a small country with a cold climate to take action are weak (Box 1). However, "taking the lead" on a global problem can be costly for an individual country like Sweden. The challenge is therefore to find a balance between the level of ambition of its climate and energy targets and the need to achieve these targets at a moderate cost. Improving the cost effectiveness of the overall framework would help reconcile these two objectives.

\section{Box 1. The political economy of climate change: some lessons from Sweden}

Climate change mitigation is a complex political economy problem (OECD, 2009a):

- Climate change is expected to have significant implications for the world economy and for many areas of human activity. When all of these impacts and more broadly the risks of inaction are factored in, ambitious global emission reduction is economically rational at the global level, meaning that global benefits would exceed global costs, provided that cost-effective solutions are in place.

- Given the current emissions growth of a number of developing countries, limiting the increase in temperature to $2^{\circ} \mathrm{C}$ would require a world coalition. Smaller coalitions could not achieve the target.

- However, most individual countries are found to gain less individually from participating than from staying outside and benefiting from the abatement efforts of other countries. Broad participation can, however, be achieved through international financial transfers.

For a country like Sweden, the incentives to "free-ride" are very large because: i) as a small country, its emissions have little impact on world emissions; ii) Sweden could benefit from at least a moderate increase in temperatures; and iii) the cost of acting alone could be high as Sweden is a small open economy with relatively high marginal abatement costs. Despite these incentives, Sweden has introduced important policies to reduce emissions. It is difficult to understand why Sweden has succeeded where several other countries have failed. Factors that may have contributed, besides the attachment Swedish citizens have to nature, include:

- Industries that could have been affected by competitiveness problems have largely benefited from exemptions from $\mathrm{CO}_{2}$ taxes.

- The extent of the change generated by the introduction of policies and how it is perceived by the population also matter. In theory, emission trading systems (ETS) are easier to introduce as they create a wellidentified domestic constituency (the permit holders) with a financial incentive to maintain the system. In practice, however, at a national level, it may be easier to create a carbon tax as it can be presented, as in the Swedish case, as a reshape of the existing taxation of energy and it is simpler than an ETS. In contrast, in France, the carbon tax was presented as an additional tax, which may have contributed to its failure. At an international level, ETS offer more possibilities to give incentives to countries to participate, for instance by more generous allocations of permits, and may therefore be easier to introduce.

- Sweden may assign a high weight to future generations. Economists have raised the question of the "appropriate" level of the carbon price. One approach is to follow a cost-benefit assessment in which the value of one tonne of $\mathrm{CO}_{2}$ is equalised to the net present value of the climate change impact of one additional tonne of $\mathrm{CO}_{2}$ emitted in the atmosphere, called the social cost of carbon. There is considerable uncertainty surrounding the estimates of the social cost of carbon because many impacts are hard to quantify. Furthermore, there are large differences between estimates because they depend largely on two controversial parameters, the social discount rate that is used to aggregate climate change impacts over time and the equity weights that are used to aggregate impacts across regions. However, for a social discount rate of $4 \%$ to $5 \%$, close to what most western governments use for long-term investments, Tol (2005) concludes from a meta survey analysis that it is unlikely that the social cost of carbon exceeds $€ 4$ per tonne of $\mathrm{CO}_{2}$. With a pure rate of time preference close to 0 , which assigns the same weight to current and future generations (as chosen in the Stern Review), the social cost of carbon would be around $€ 70$ per tonne of $\mathrm{CO}_{2}$, much closer to the Swedish value (the general level of the $\mathrm{CO}_{2}$ tax is above $€ 100$ per tonne of $\left.\mathrm{CO}_{2}\right){ }^{2}$

1. The social discount rate measures the importance of the welfare of future generations relative to the present for society as a whole.

2. In 2010, the general level of the $\mathrm{CO}_{2}$ tax was $\mathrm{SEK} 1050$ or $€ 111$ per tonne of $\mathrm{CO}_{2}$. 


\section{Sweden, a clean country with ambitious GHG emission reduction targets}

Sweden has adopted national targets that are more ambitious than the ones set at the international level. This is commendable. For 1990-2012, while Sweden's commitment under the Kyoto Protocol was to limit the increase in GHG emissions to 4\%, the country has decided to reduce its emissions by 4\% (Box 2). Beyond 2012, as for other EU countries, Sweden's GHG emissions are constrained by the EU Climate and Energy Package and the 20-20-20 targets to be met by 2020. At the EU level, participants have agreed to reduce EU GHG emissions by at least $20 \%$ relative to 1990 levels, to have $20 \%$ of EU energy consumption come from renewable energy and to improve energy efficiency by $20 \%$. These targets are to be achieved through emission reductions in sectors both covered and not covered by the EU emission trading system (EU ETS). Sweden has agreed to take a significant share of the effort to reduce GHG emissions in sectors not covered by the EU ETS by adopting a more than $20 \%$ emission reduction target in these sectors, which is the most stringent target adopted among EU member countries. The country will also contribute significantly to the EU renewables target by raising the share of renewable energy in Sweden to at least $50 \%$.

\section{Box 2. Main national and international climate change mitigation targets applying to Sweden}

\section{Targets for 2012}

Under the Kyoto protocol, Sweden should limit its GHG emissions to no more than 4\% above 1990 levels for the average level of GHG emissions over the period 2008-12.

However, Sweden has also adopted a more stringent target for the same period, which is to reduce the average level of emissions over 2008-12 by $4 \%$ from the 1990 level. The target is to be achieved without resorting to carbon sinks or flexible mechanisms such as the Clean Development Mechanism (CDM), even though the latter is allowed under the Kyoto protocol.

Targets for 2020

\section{EU targets}

As an EU member, Sweden has to contribute to the achievement of EU targets for 2020, which are:

- A $20 \%$ reduction in GHG emissions relative to 1990 levels. This reduction can be scaled up to as much as $30 \%$ should there be a new global climate change agreement with other developed countries making comparable efforts.

- $\quad$ That $20 \%$ of EU energy consumption be from renewables.

- A $10 \%$ share for renewable energy in the transport sector.

- $\quad$ A $20 \%$ reduction in primary energy use compared with projected levels, to be achieved by improving energy efficiency.

These targets have to be fulfilled at the EU level. Richer countries are expected to contribute more than poorer ones. For Sweden, the specific targets are:

- A decrease in emissions of sectors outside the EU ETS by $17 \%$ between 2005 and 2020. This is the consequence for Sweden of the Effort Sharing Decision under which Member States have agreed to a binding national emissions limitation target for 2020 for uncovered sectors reflecting each Member State's relative wealth. The targets range from an emissions reduction of $20 \%$ by the richest Member States to an increase in emissions of $20 \%$ by the poorest. These national targets will cut the EU's overall emissions from the non-ETS sectors by $10 \%$ by 2020 compared with 2005 levels.

- An increase in the share of energy from renewable energy sources from $40 \%$ in 2005 to $49 \%$ in 2020 . 


\section{National targets}

In addition to these EU targets, Sweden has also adopted three targets (Government bills 2008/09:162 and 163):

- $40 \%$ reduction relative to 1992 in GHG emissions for sectors not covered by the EU ETS (transport, housing, waste facilities, agriculture, forestry, aquaculture and some parts of industry). One third of the target is to be achieved through investments in other EU countries or in flexible mechanisms such as the CDM. The remaining two-thirds will have to be achieved in Sweden, corresponding to a decrease by around $30 \%$ in Sweden over 1990-2020.

- At least $50 \%$ renewable energy, which is slightly above the EU target.

- $20 \%$ reduction in energy intensity by 2020 relative to 2008 .

The government has also stated its ambition to have a vehicle stock that is independent of fossil fuel energy by 2030.

Sweden is expected to fully meet both its Kyoto protocol and its national targets for 2008-12. By 2008 GHG emissions were almost $12 \%$ below their 1990 level, one of the largest GHG emission reductions achieved by OECD countries (Figure 3, Panel A). Sweden's performance, as with some other European countries, also shows that it is possible to "decouple" GHG emissions growth from GDP growth since GDP has more than doubled over the same period (Figure 4.4). Sweden is now one of the countries with the lowest emissions per capita (Figure 3, Panel B).

Emissions have been mainly reduced in services and the residential sector, where the use of oil for heating has been largely replaced by district heating based on biomass fuels (Figure 5, Panel A). To a lesser extent, emissions also decreased in the energy supply and the waste sectors. In contrast, they have continued to increase in the transport sector, which is now the main source of GHG emissions (Figure 5, Panel B). 
Figure 3. GHG emissions in Annex I countries, trend and level
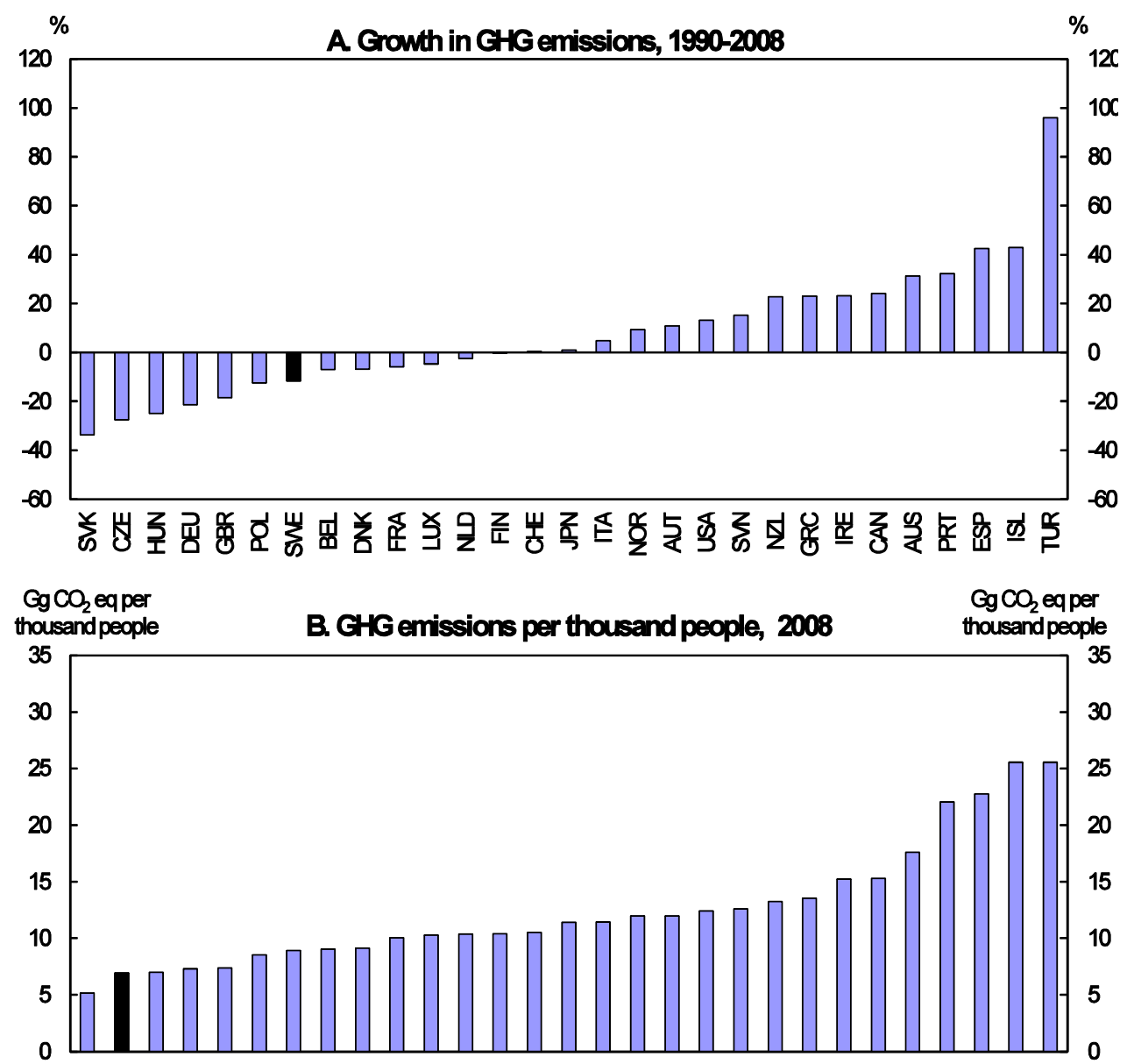

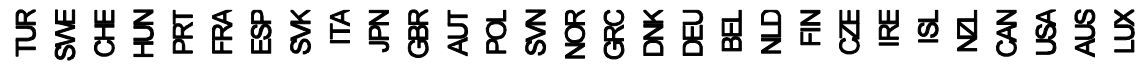

Source: Source:UNFCCC.

Figure 4. GHG emissions and GDP in Sweden

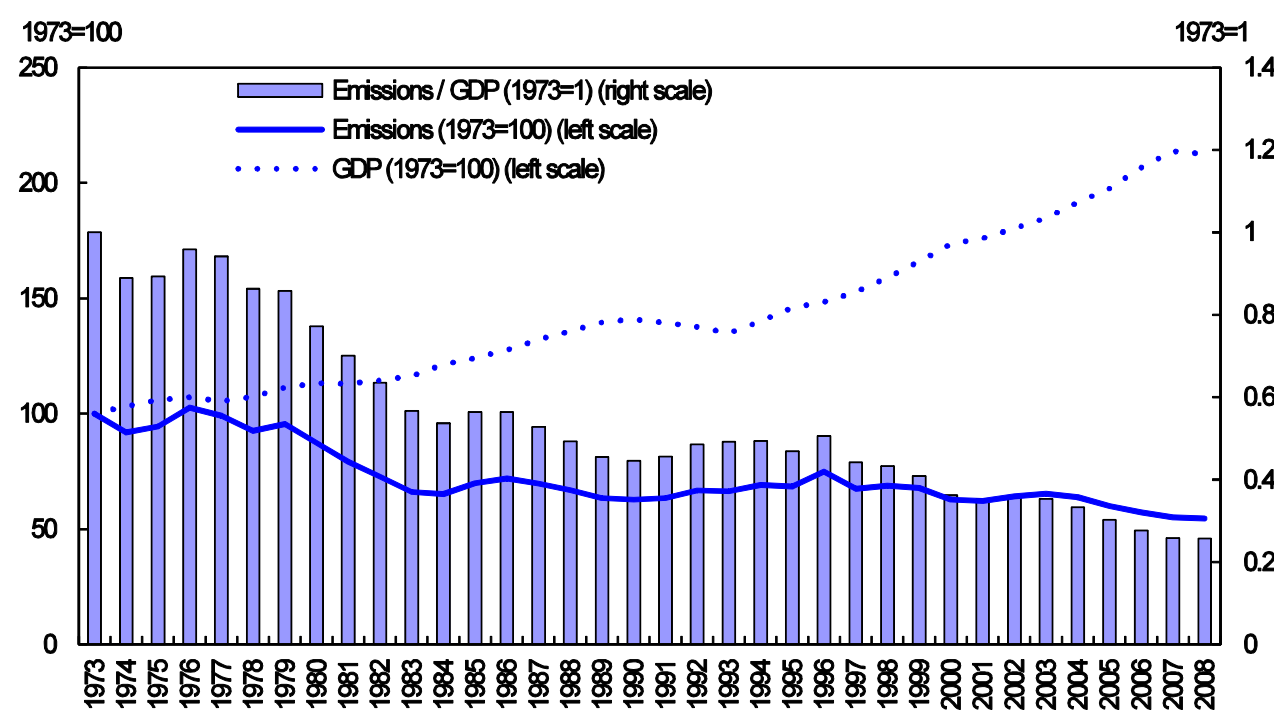

Source: IEA (2009b) and OECD (2010b). 
Figure 5. GHG emissions by sectors, 1990-2008

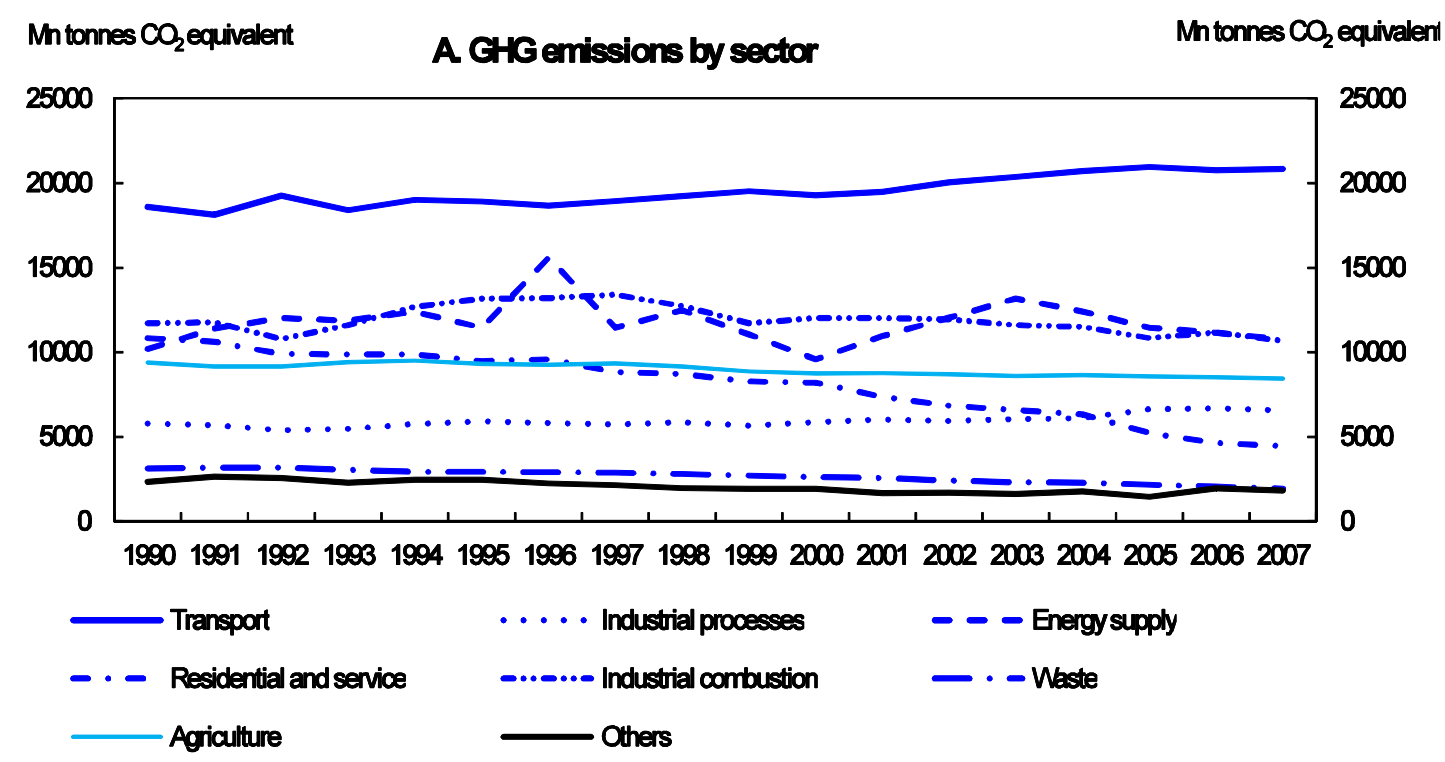

\section{B. Share of $\mathrm{GHG}$ emission by sector, 1990}

\section{Share of GHG emission by sector, 2007}
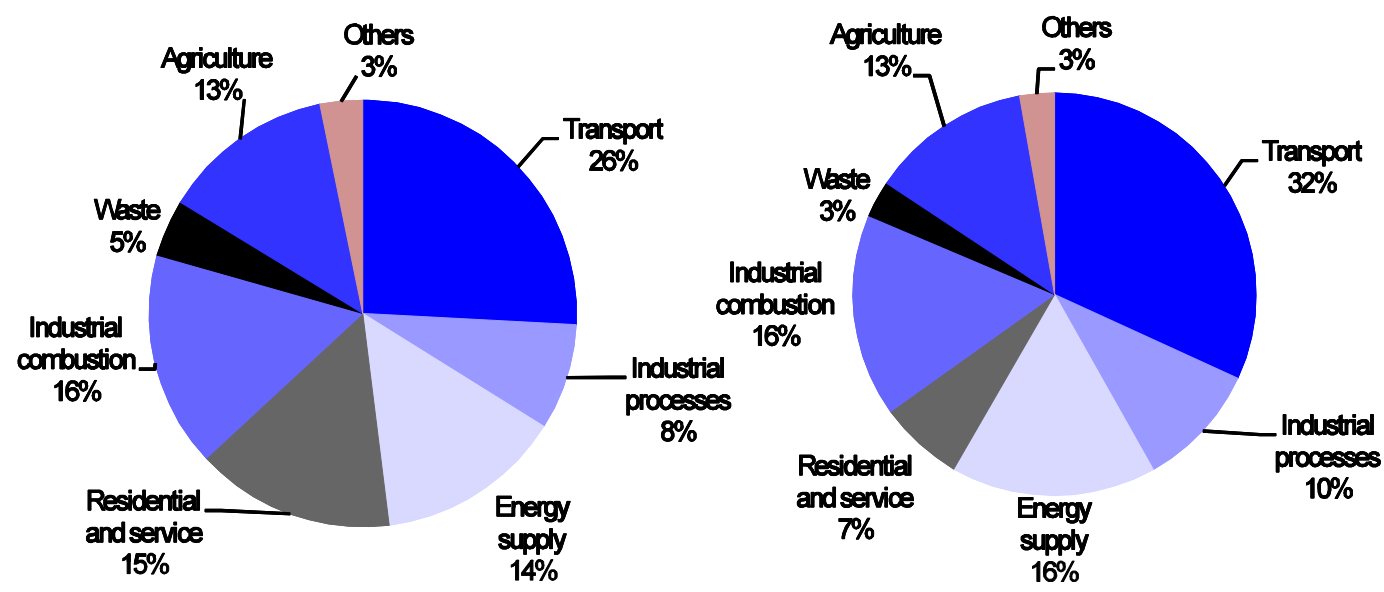

Source: Ministry of the Environment (2009).

Sweden managed to reduce its GHG emissions per capita by mainly lowering GHG emissions per unit of energy, i.e. by "cleaning" its energy (Table 1). Over the past four decades, this mainly reflected the development of nuclear energy (Figure 6). Over a shorter period of time, the development of energy from renewable sources, mainly electricity from hydroelectric power generation and imports of biofuels, has also contributed. The share of renewable energy has increased from 34\% in 1991 to $44 \%$ in 2007 and is among the highest in OECD countries (Figure 7). Electricity is now almost $\mathrm{CO}_{2}$-free with hydro-electricity and nuclear power accounting for more than $90 \%$ of electricity generation. 
Table 1. Decomposition of GHG emissions in selected countries

\begin{tabular}{|c|c|c|c|c|}
\hline \multicolumn{5}{|c|}{2005} \\
\hline & GHG emissions / population ${ }^{2}$ & $\begin{array}{c}\text { GDP / } \\
\text { population }^{3}\end{array}$ & $\begin{array}{l}\text { Energy / } \\
\text { GDP }^{4}\end{array}$ & $\begin{array}{c}\text { GHG emissions } \\
/ \text { energy }^{5}\end{array}$ \\
\hline Sweden & 7.9 & 32.3 & 0.179 & 1.369 \\
\hline Canada & 22.9 & 35.1 & 0.24 & 2.70 \\
\hline Denmark & 12.6 & 33.3 & 0.11 & 3.46 \\
\hline France & 9.0 & 30.6 & 0.15 & 1.99 \\
\hline Germany & 11.9 & 31.4 & 0.13 & 2.83 \\
\hline Italy & 9.7 & 28.4 & 0.11 & 3.03 \\
\hline Japan & 11.1 & 30.3 & 0.14 & 2.68 \\
\hline UK & 10.5 & 32.2 & 0.12 & 2.69 \\
\hline USA & 23.7 & 41.9 & 0.19 & 2.99 \\
\hline OECD average & 14.1 & 29.7 & 0.16 & 2.95 \\
\hline \multicolumn{5}{|c|}{$\%$ change between 1990 and 2005} \\
\hline & GHG emissions / population ${ }^{2}$ & $\begin{array}{c}\text { GDP / } \\
\text { population }^{3}\end{array}$ & $\begin{array}{c}\text { Energy / } \\
\text { GDP }^{4}\end{array}$ & $\begin{array}{c}\text { GHG emissions } \\
/ \text { energy }^{5}\end{array}$ \\
\hline Sweden & -9.5 & 31.2 & -20.7 & -13.0 \\
\hline Canada & 9.9 & 29.8 & -13.6 & -2.0 \\
\hline Denmark & -11.0 & 30.6 & -20.1 & -14.7 \\
\hline France & 17.5 & 22.4 & -8.1 & 4.4 \\
\hline Germany & -23.7 & 22.0 & -23.4 & -18.4 \\
\hline Italy & 8.9 & 19.3 & 2.6 & -11.0 \\
\hline Japan & 8.6 & 16.9 & -1.5 & -5.7 \\
\hline UK & -14.3 & 36.5 & -23.1 & -18.4 \\
\hline USA & -1.3 & 31.1 & -21.7 & -3.8 \\
\hline OECD average & 2.1 & 29.6 & -15.2 & -7.2 \\
\hline
\end{tabular}

1. $\mathrm{GHG}$ emissions/population $=(\mathrm{GDP} /$ population $){ }^{*}$ (energy/GDP $){ }^{*}(\mathrm{GHG}$ emissions/energy $)$.

2. In tonnes of $\mathrm{CO}_{2}$ eq per head.

3. In thousand US\$ using PPP exchange rates for the year 2000.

4. For total final energy consumption in ktoe/billion PPP US $\$$ for the year 2000.

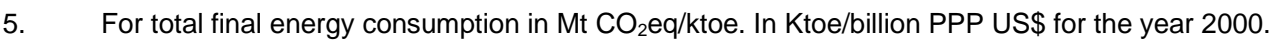

Source: IEA and OECD calculations.

While the energy intensity of GDP (the ratio of energy consumption over GDP) has also declined, it remains above the OECD average. This is because Sweden's industry is very energy-intensive and energy consumption by households is high due to the cold climate.

The land use, land-use change and forestry (LULUCF) sector has sequestered more carbon over 1990-2007 than it has released. Lands and forests are part of a natural cycle regulating the amount a carbon in the earth's atmosphere. Carbon sequestration rates depend on how land is used, on biomass and soil types, and on regional climate and topography. For instance, the conversion of forests to agricultural land increases the stock of GHGs in the atmosphere because most forests usually absorb more $\mathrm{CO}_{2}$ than agricultural land while afforestation and reforestation sequester $\mathrm{CO}_{2}$ over decades. However, the carbon sink has been shrinking faster since 2002 because of increased felling and a severe storm in 2005 . 
Figure 6. Energy supply 1970-2007

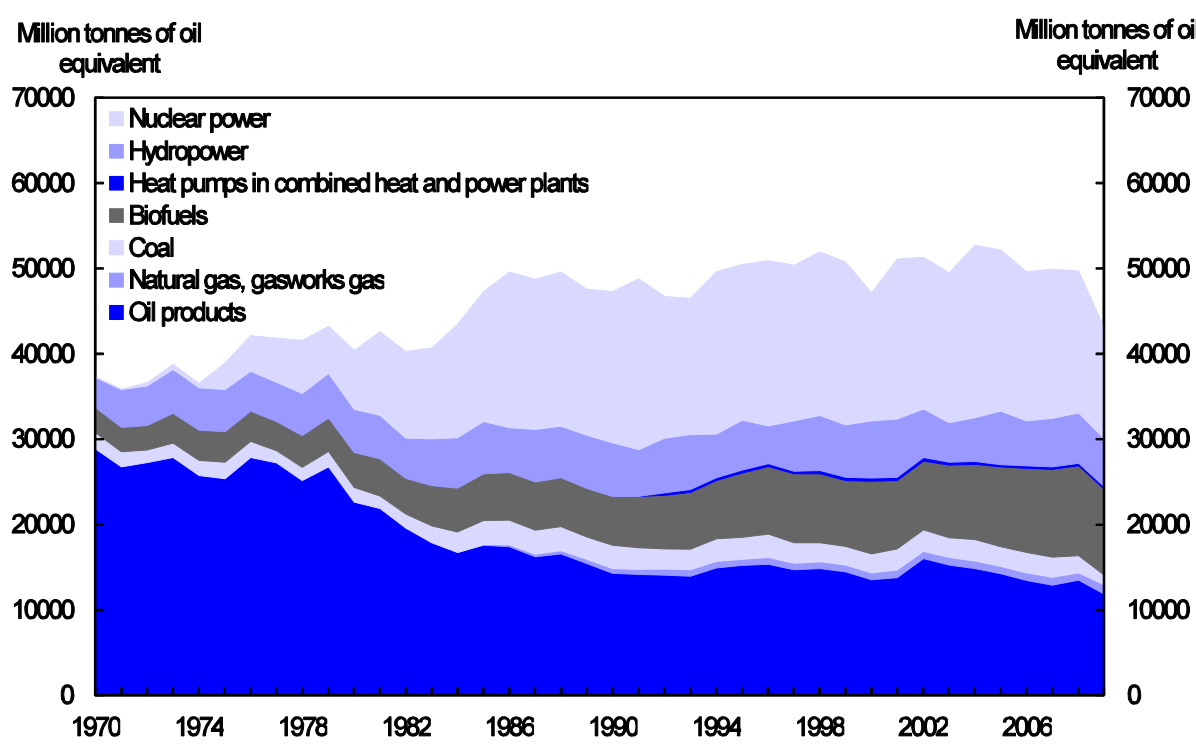

Source: IEA (2010a).

Figure 7. Share of renewable energy in total energy supply in Sweden and OECD
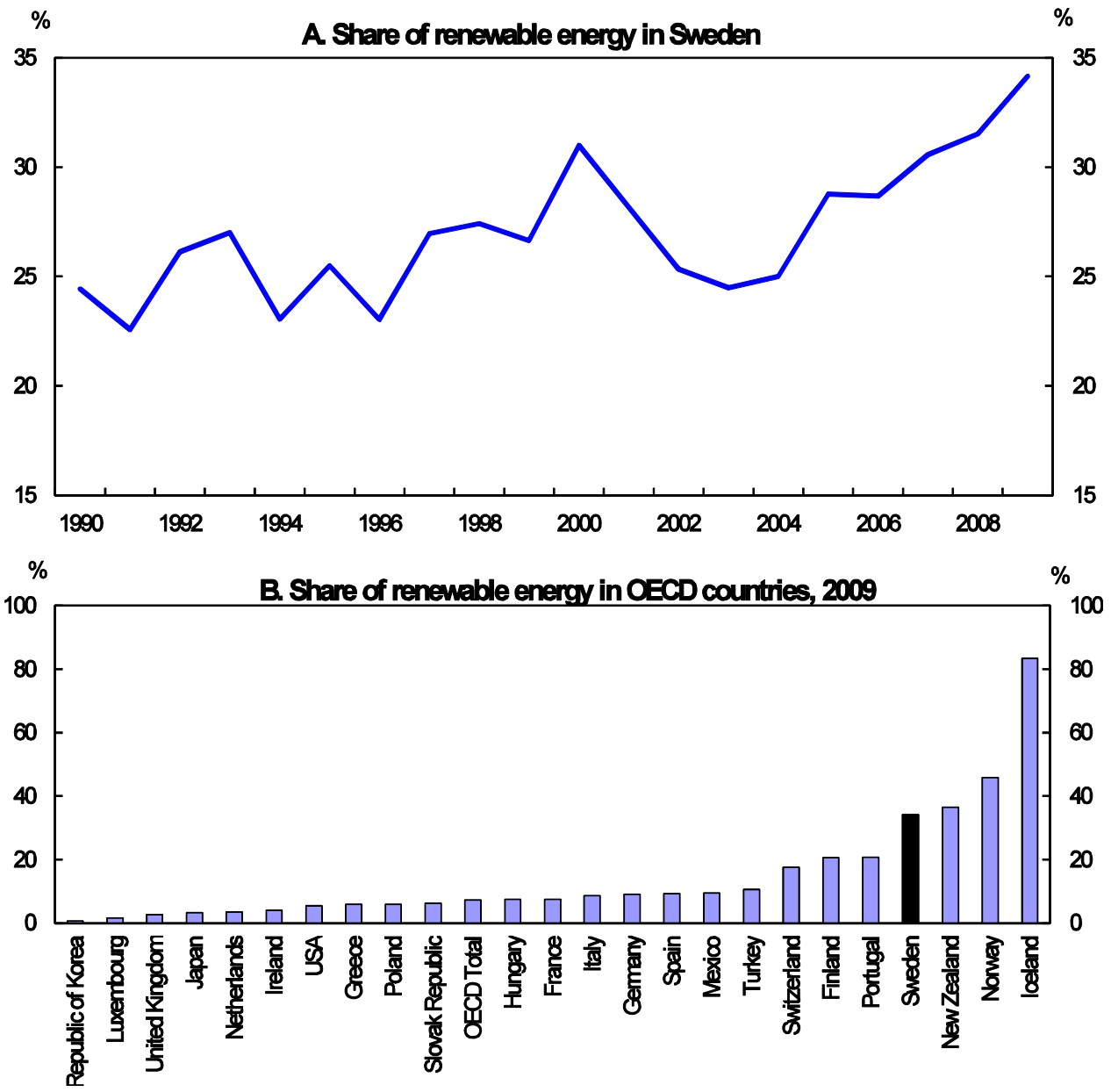

Source: IEA (2010b) 


\section{The policy framework to mitigate climate change}

The laudable results reviewed above stem from a long tradition of climate change mitigation policies (Annex 1). Sweden has made extensive use of market-based instruments (carbon tax and participation in the EU ETS) but has also developed several other instruments such as performance and technology standards, various forms of support to R\&D in "green" technologies and subsidies to some investments. Assessing the cost-effectiveness of this policy framework raises the issue of the benchmark against which they should be judged. As climate is a global public good, cost-effective policies to combat climate change need to be broad-based in terms of countries, sectors and gases. Compared to that benchmark, actions by a single country or group of countries are likely to fail the cost-effectiveness criterion. Furthermore, as competitiveness losses are expected to be larger when a small open economy is acting alone, the risk of having some exemptions in policies, which lowers further the cost-effectiveness of the overall policy framework, is larger. For these reasons, Sweden's policies should be assessed relative not to what they should be under a cost-effective international agreement to mitigate GHG emissions but to a second-best solution in which the cost is minimised given the large set of constraints that come from the lack of an international mitigation agreement.

\section{Most sectors are covered by market-based instruments}

The rationale for market-based instruments is simple. GHG emissions are a by-product of economic activities, and carry a social cost as they adversely impact the world economy and human well-being. The main market mechanism for internalising the social cost of carbon is to put a price on carbon, either through carbon taxes or an ETS. In theory, the difference between the two instruments is that under a carbon tax system, the price of carbon is fixed and the size of emission reductions is uncertain, whereas under an ETS, the size of emission reductions is known while the carbon price fluctuates. In practice, however, as carbon tax rates are usually changed over time and financial markets allow firms to hedge against short-term fluctuations of the carbon price under an ETS system, the two instruments are very similar. The major difference may be their capacity to allow burden sharing (OECD, 2009a). A number of market failures justify complementing market-based instruments with other instruments (Box 3). However, a basic principle is that overlaps of instruments are generally costly and therefore, non market-based instruments should be used only when there is a market failure that cannot be fully addressed by a carbon price.

\section{Box 3. Designing a cost-effective set of climate mitigation policy instruments}

A cost-effective set of instruments to achieve any given climate mitigation objective should meet three broad criteria (Duval, 2008):

- Equalise marginal abatement costs across all emission sources in order to fully exploit existing opportunities for low-cost GHG emission reductions. This requires the instrument to be cost-effective per se but also to be applied as widely as possible across countries, sectors and GHGs.

- Foster an efficient level of innovation and diffusion of GHG emission-reducing technologies in order to lower future marginal abatement costs.

- $\quad$ Cope effectively with risks and uncertainties surrounding both climate change and abatement costs.

While a carbon price, coming either from a tax or an ETS, meets these three criteria, there are a number of market imperfections that justify complementing a carbon price with other instruments:

- The most obvious market imperfection comes from the global public good nature of the climate, which leads to free rider problems and makes it inherently difficult to achieve broad participation. This justifies having some forms of support to countries/sectors with weak incentives to participate.

- Monitoring and enforcement costs can be large for certain emission sources such as deforestation or methane emissions resulting from pipeline leakage, justifying the adoption of some regulatory standards. 
- Information problems: imperfectly informed households and firms may act inefficiently even if faced with adequate incentives. For example, the energy efficiency of buildings may be hampered by divergent incentives and asymmetric information between landlords and tenants. Some standards and information instruments such as labeling could help in this regard.

- Capital market imperfections may affect the ability of households and small firms to invest in profitable energy-saving equipment with high fixed costs. Some forms of subsidies can mitigate this problem.

Sweden was one of the first countries to introduce a carbon tax in 1991. At that time, the tax was supposed to cover all sectors, although a large number of them benefit from significantly lower tax rates (see below). With the introduction of the EU ETS in 2005, sectors that were covered by the carbon tax also had to face the EU ETS carbon price. The EU ETS covers installations in the production of electricity and in the heating sector, refineries, installations that produce and process iron, steel, glass and glass fibre, cement and ceramics and installations that produce paper and pulp. Most emissions from the transport sector and from households are excluded. To avoid double regulation, the government decided to exempt the industries covered by the EU ETS from the carbon tax. Hence, all sectors are covered by a carbon price, but it varies greatly across firms and sectors with some activities being fully exempted (Table 2).

Table 2. Main instruments affecting GHG emissions in Sweden

\begin{tabular}{|c|c|c|}
\hline & Price instruments & Other instruments \\
\hline Energy supply & $\begin{array}{l}\text { - EU ETS, covering } 33 \% \text { of } \\
\text { emissions in } 2007 \\
\text { Energy and } \mathrm{CO}_{2} \text { taxes covering } \\
\text { the remaining part of emissions, } \\
\text { with exemptions (in general, } 21 \% \\
\text { of the general rate) }\end{array}$ & $\begin{array}{l}\text { - Electricity certificate system } \\
\text { - } \quad \text { Special initiatives for wind and } \\
\text { solar power }\end{array}$ \\
\hline Industry & $\begin{array}{l}\text { EU ETS covering almost all } \\
\text { emissions } \\
\text { Energy and } \mathrm{CO}_{2} \text { taxes for } \\
\text { industries not covered by the EU } \\
\text { ETS. Exemptions: in general, } \\
21 \% \text { of the general rate. }\end{array}$ & $\begin{array}{l}\text { - } \quad \text { F-gas regulation } \\
\text { - } \quad \text { Programme for energy efficiency } \\
\text { in industry }\end{array}$ \\
\hline Transport & - Energy and $\mathrm{CO}_{2}$ taxes & $\begin{array}{ll}\text { - } & \mathrm{CO}_{2} \text { requirements for new } \\
& \text { vehicles } \\
\text { - } & \text { Tax exemption for biofuels/ quota } \\
\text { - } & \text { obligations } \\
\text { - } & \mathrm{CO}_{2} \text { differentiated vehicle tax } \\
\text { - } & \text { Definition of green car } \\
\text { - } \quad \text { Infrastructure planning } \\
\end{array}$ \\
\hline Residential and services & - Energy and $\mathrm{CO}_{2}$ taxes (full rate) & $\begin{array}{ll}\text { - } & \text { Energy declaration } \\
\text { - } & \text { Building regulation } \\
\text { - } & \text { Energy advice } \\
\text { - } & \text { Technology procurement } \\
\text { - } & \text { Energy labelling }\end{array}$ \\
\hline Agriculture & $\begin{array}{l}\text { Energy and } \mathrm{CO}_{2} \text { taxes }(21 \% \text { of } \\
\text { the general rate) }\end{array}$ & $\begin{array}{ll}\text { - } & \text { Support for biogas } \\
\text { - } & \text { Rural development programme }\end{array}$ \\
\hline Total economy & $\begin{array}{l}\text { - } \quad \text { EU ETS covering } 32 \% \text { of } \\
\text { emissions in } 2007 \\
\text { - } \quad \text { Energy and } \mathrm{CO}_{2} \text { taxes covering } \\
68 \% \text { of emissions in } 2007\end{array}$ & $\begin{array}{l}\text { - } \quad \text { Climate investment programmes } \\
\text { Research and development } \\
\text { public policies }\end{array}$ \\
\hline
\end{tabular}

Source: Ministry of the Environment (2009a) and OECD. 


\section{The carbon tax interacts with the energy tax and includes several exemptions}

In Sweden, carbon is taxed both directly through the $\mathrm{CO}_{2}$ tax, which puts a price on each unit of $\mathrm{CO}_{2}$ that is emitted, and indirectly through the energy tax on fossil fuels. The statutory carbon tax rate has been increased from $€ 27$ to $€ 110$ per tonne of $\mathrm{CO}_{2}$ between 1991 and 2010 (Figure 8). The energy tax, which predates the carbon tax, does not directly depend on the $\mathrm{CO}_{2}$ content of fuels but implicitly puts a price on carbon, albeit not uniformly so. The overall (both direct and indirect) tax rates on fossil fuels and electricity are among the highest in Europe with households and services being more heavily taxed than industry, a feature shared with other European countries (Figure 9, ADEME, 2009). The overall tax rate per tonne of $\mathrm{CO}_{2}$ varies across fossil fuels and is smaller for coal than for others because the energy tax is not uniform, but to a lesser extent than in some other European countries that generally only have an energy tax (ADEME, 2009).

Figure 8. Evolution of the general $\mathrm{CO} 2$ tax rate in Sweden

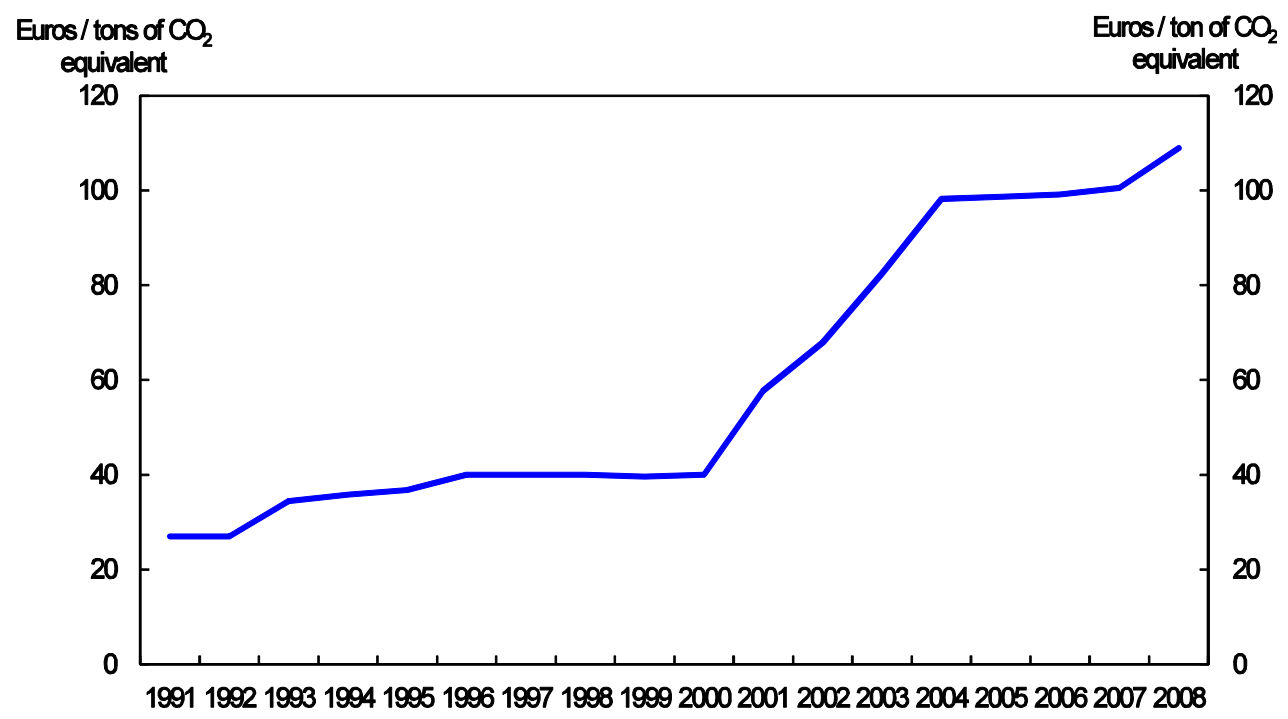

Source: Swedish Ministry of Finance.

Not only does $\mathrm{CO}_{2}$ taxation vary among fossil fuels but it also varies across sectors, because there are several exemptions, both to the carbon tax and to the energy tax (Figure 9). For instance, in 2010 industry, agriculture, forestry and aquaculture pay $21 \%$ of the general level of the carbon tax although this will be increased to $30 \%$ in 2011 and $60 \%$ in 2015 . Petroleum, mineral products, and metals industries, and water and air transport are fully exempted although some of these sectors are now covered by the EU ETS carbon price (see below). Revenues from the carbon tax come mainly from the household and transport sectors. This heterogeneity in tax rates lowers the cost-effectiveness of the instrument because emission abatements are made in sectors (and for fossil fuels) where tax rates are the highest and not necessarily where marginal abatement costs are the lowest. 
Figure 9. Implicit tax rates on CO2 in OECD countries and in Sweden
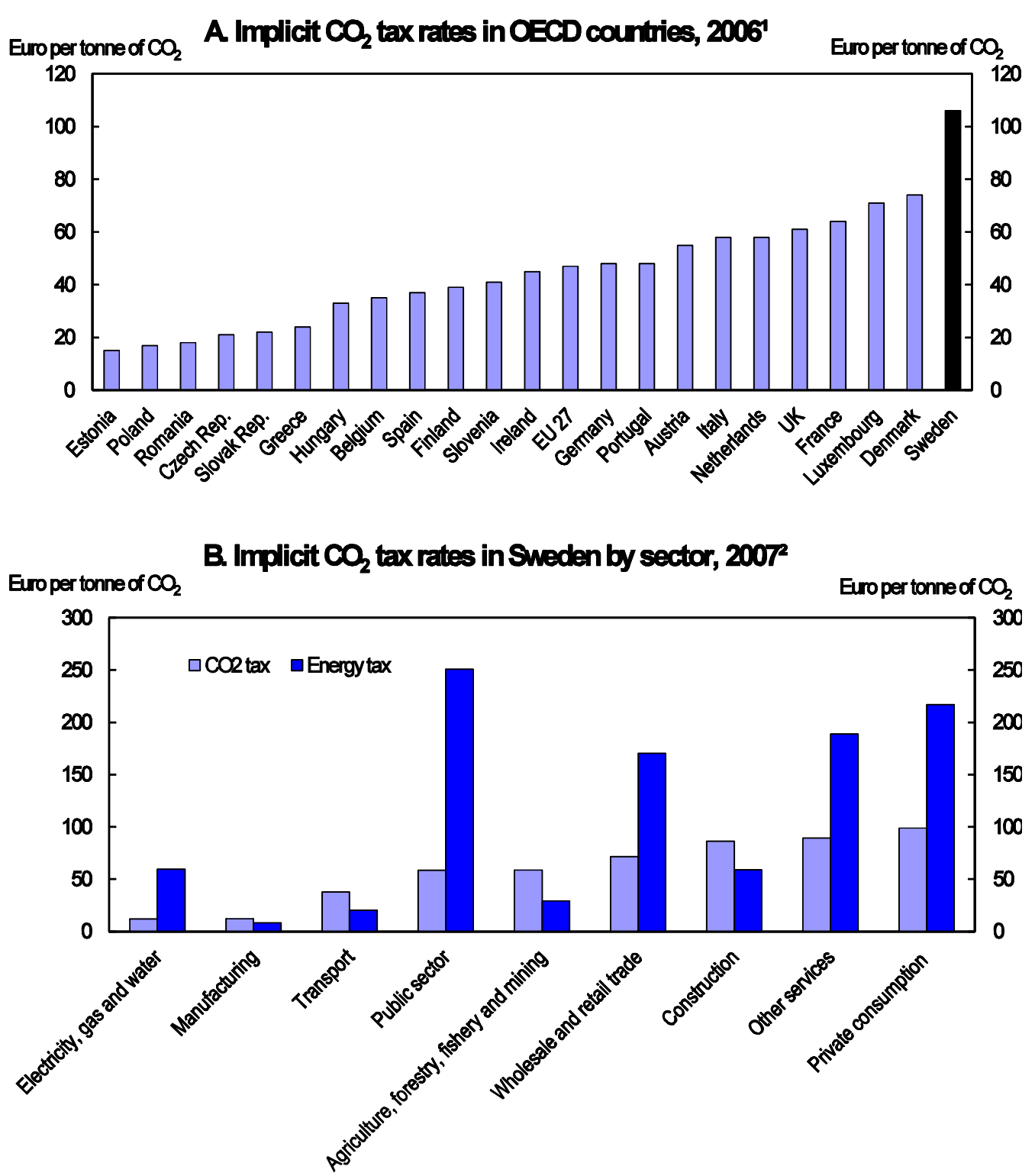

1. Implicit $\mathrm{CO}_{2}$ tax rates (computed by ADEME, 2009) presented in Panel A are computed by dividing the sum of the revenues from the taxes on fossil fuel and on electricity (generated from fossil fuel) by $\mathrm{CO}_{2}$ emissions. In the case of Sweden, it includes revenues from the $\mathrm{CO}_{2}$ tax and the energy tax.

2. Implicit tax rates on $\mathrm{CO}_{2}$ are computed by dividing the revenues from the $\mathrm{CO}_{2}$ tax (energy tax) by $\mathrm{CO}_{2}$ emissions. Measures have been decided by the Swedish Parliament, entering into force in 2011, 2013 and 2015, that will reduce the heterogeneity in $\mathrm{CO}_{2}$ and energy tax rates.

Source: ADEME (2009) and Statistics Sweden, National Environmental Accounts.

The exemptions are justified by the Government as a way to minimise the "leakage" problems that arise when one country (or group of countries) decides to act alone. The main source of carbon leakages for Sweden is related to the risk that Swedish carbon-intensive industries lose market share to their foreign competitors and/or reallocate capital to non-participating countries, so that part of the emission reductions in Sweden are offset by increases elsewhere. ${ }^{2}$ Quantitative analysis suggests that, leakages are larger for a small coalition, but also that they are often exaggerated as the carbon tax rate is only one input to location 
decisions and other countries also tax energy-intensive industries (Barker et al., 2007; OECD, 2009a). Another reason for these tax exemptions is to limit energy-intensive industries' output losses. However, energy-intensive industry losses mainly reflect that opportunities to lower emissions at the lowest cost are in their sectors and would happen even in the absence of competitiveness problems. This is part of the reallocation process within and between sectors from carbon-intensive activities towards less intensive ones. For instance, according to OECD simulations, under a global scenario where world emissions are reduced by $50 \%$ by 2050 relative to 1990 , and hence, where there is no leakage, the output of energyintensive industries would be reduced by $12 \%$.

An energy tax that indirectly taxes $\mathrm{CO}_{2}$ emissions on top of the carbon tax makes the price signal on carbon less clear to firms and households. The energy tax was originally introduced mainly to raise revenues. However, it is now used by the government as an instrument to meet other targets as well (Ministry of Finance, 2009). As the energy tax rate is higher for oil than for natural gas, with oil having a higher carbon content and leading to more GHG emissions, the energy tax helps meet the GHG emission target. Taxing fossil energy also helps to fulfil the energy intensity target and, as there are several exemptions for biofuels, it is used to meet the renewables targets. Finally, the energy tax is supposed to address other externalities. Using one instrument to achieve several targets runs the risk of missing some of the targets. In theory, it would be best to have one instrument per objective, i.e. one tax to raise revenues, one uniform tax on $\mathrm{CO}_{2}$ to contain GHG emissions and one or several taxes to address other pollutants. In practice, however, it is difficult to disentangle the second and third objectives as activities that generate GHG emissions also lead to other pollutant emissions, and vice versa (Bollen et al., 2009). Proposals to change the structure of energy and $\mathrm{CO}_{2}$ taxation were made by the Government Commission on Green Taxation in 1997 (Swedish Government Inquiries, 1997).

The carbon and the energy taxes have contributed to the decrease in GHG emissions, although it is difficult to know to what extent as there are few evaluations of their impact (Andersen, 2004). The use of several policy instruments that interact in the area of climate change makes it difficult to assess the impact of each instrument and in particular of the carbon tax (Ministry of the Environment, 2009). However, the carbon tax is considered to have caused emission reductions mainly in the residential sector (district heating mostly) and has mitigated the trend increase in emissions in transport. Its impact on industry is probably small as this sector benefits from large exemptions (Johansson, 2000). The most recent estimate using a computational general equilibrium model dates back to 1997, and suggested that a doubling of the $\mathrm{CO}_{2}$ tax would lead to reductions of Swedish $\mathrm{CO}_{2}$ emissions by $0.1 \%$ to $1.7 \%$ (Swedish Government Inquiries, 1997). Extrapolating this result to the period 1991-2010, during which the general level of the tax has been multiplied by four, would imply that a reduction in GHG emissions by $0.2 \%$ to $3.5 \%$ could have been achieved through the $\mathrm{CO}_{2}$ tax. ${ }^{3} \mathrm{~A}$ recent study using firm level data shows that $\mathrm{CO}_{2}$ emissions of firms in the manufacturing sector have been very sensitive to the $\mathrm{CO}_{2}$ tax, even though the tax has been low up to now in these sectors (Brännlund et al., 2010).

\section{The EU ETS should allow Sweden to finance emission reductions in other European countries}

Sweden is participating in the EU ETS that was introduced as a tool to help EU countries meet their obligations under the Kyoto protocol. Despite some failures during the first phase of the system, which was mainly a trial period, the EU ETS has successfully led to the emergence of a carbon price and the volume of transactions has steadily increased since 2005 (Figure 10). A commitment period (Phase II) is running from 2008 until 2012 to coincide with the commitment period of the Kyoto protocol, and the system is scheduled to continue beyond that horizon, with an extension of its coverage. ${ }^{4}$ In Sweden, the EU ETS covers only one third of the $\mathrm{CO}_{2}$ emissions, as against close to one half at the EU level, mainly because emissions in the electricity sector are very low in Sweden. 
Figure 10. EU ETS carbon price

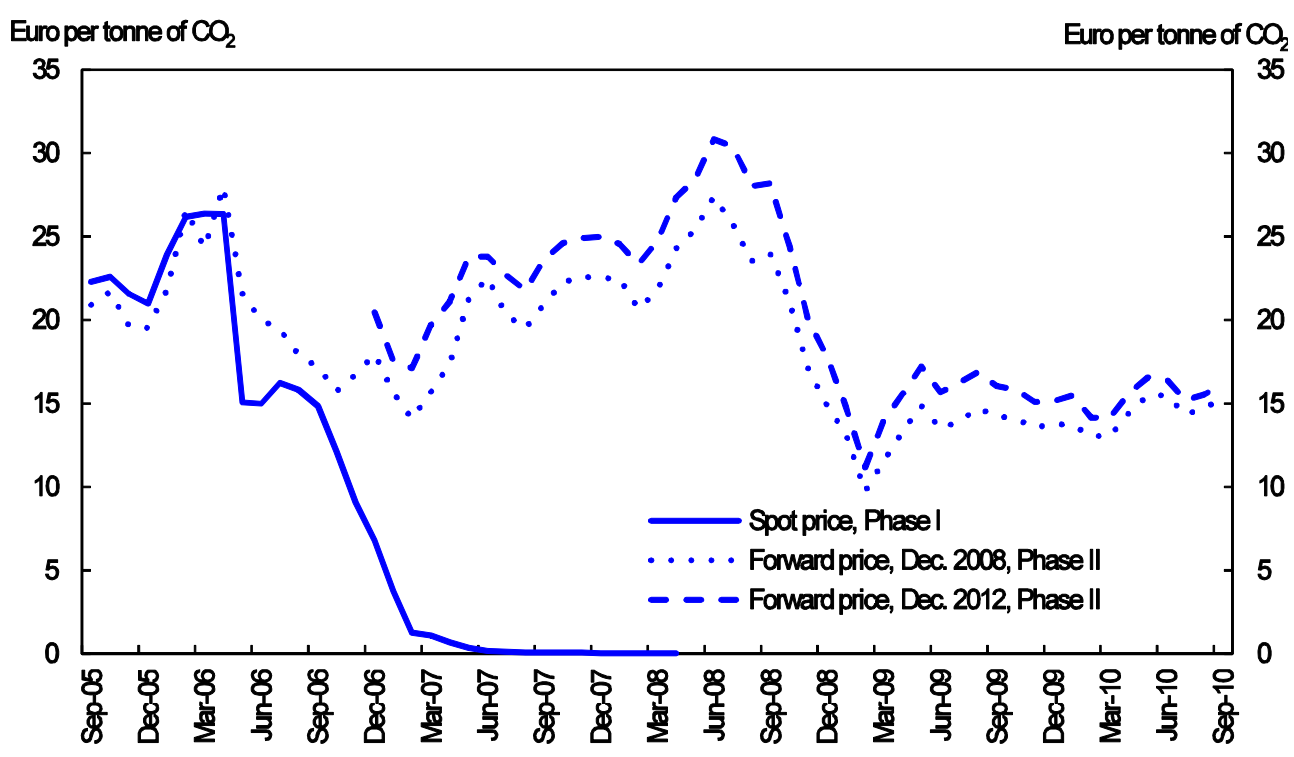

Source: Point Carbon and Caisse de Dépôts (2010), Tendances Carbone No.52 November.

Under the EU ETS, the cap in emissions is set at the EU level and firms trade allowances within and between countries. Where the emission reductions are done depends on the marginal abatements costs. Firms and countries with low marginal abatement costs take actions to lower their emissions and then sell their allowances (in the case where they are allocated free of charge ${ }^{5}$ ) while those with high marginal costs continue to emit and buy the allowances.

While marginal costs depend on country-specific characteristics, they also tend to increase with the level of emission reductions. As a result, the EU ETS should allow countries like Sweden, with relatively high marginal costs, to finance emission reductions in other EU countries where it is cheaper, thereby helping them to lower their average abatement cost (Hill and Kriström, 2002). ${ }^{6}$ With a binding allocation of permits, countries with relatively high marginal costs would buy permits while countries with relatively low marginal costs would sell permits. In practice, the allocation of allowances for Sweden over 2008-12 ( 22.3 million tonnes of $\mathrm{CO}_{2} \mathrm{eq}$ ) is expected to be $2 \%$ above the projected emissions for sectors covered by the EU ETS, implying that Sweden could be a net seller of allowances over the period. One reason for Sweden being a potential net seller although it faces relatively high marginal costs, could be that policies to develop renewables in the electricity sector (see below) have induced emission reductions in addition to those coming from the EU ETS carbon price in sectors covered by the EU ETS. The carbon tax also affects emissions in sectors covered by the EU ETS through general equilibrium effects such as by increasing the price of intermediate goods that are subject to the carbon tax. Over 2008-12, these additional emission reductions in Swedish sectors covered by the EU ETS will be partly offset by lower emission reductions in other EU countries. However, for future commitment periods under the EU ETS, the impact of other policies on GHG emissions in sectors covered by the EU ETS would warrant a more restrictive allocation to Sweden.

\section{The electricity certificate system has boosted the development of renewable energy but at a high cost}

In addition to its GHG emission objectives, Sweden has developed energy from renewable sources. The electricity certificate system is the main instrument used by Sweden to develop renewables in the electricity sector. Under this system, electricity producers (and some users) are required to purchase certificates equivalent to a certain proportion (quota) of their sales (or use). This creates a demand for 
certificates. ${ }^{7}$ Producers of electricity from renewable energy sources receive an electricity certificate for every megawatt-hour of electricity produced. This creates a supply for certificates. The price of the certificates depends on supply and demand and, in turn, on the size of the quota obligation, which is adjusted every year by the government to generate an increasing demand for certificates. It is expected that the price of the certificates is, in the end, passed on to consumers, thereby lowering demand for fossil-fuel based electricity. The quota has been binding since $2005 .{ }^{8}$ Electricity-intensive industries are exempted to avoid competitiveness problems. Similar systems exist in Belgium, Italy, Norway, Poland and the United Kingdom.

The pros and cons of electricity certificate systems have been discussed at length in the literature. ${ }^{9}$ Two issues stand out. The first is whether there is a need to support specific carbon-free technologies beyond the incentives generated by carbon pricing. One reason is that R\&D spending on renewables technologies entails some fixed costs and firms bearing the investment cost cannot be certain to appropriate all of the associated benefit because of spillover effects to other firms. These market failures justify combining a carbon price and public policies to support R\&D for these technologies.

The second issue pertains to determining which additional supports are the most cost-effective to boost innovation in low-carbon technologies in the electricity sector. The main argument in favour of the certificate system is that it is market-based. Producers can choose among several technological options, which encourages innovation in technologies that have the lowest cost. In contrast, feed-in tariffs, which support renewables via a guaranteed price (that may vary by technology), do not necessarily encourage investment in technologies with the lowest costs.

Empirical analysis shows that electricity certificate systems have a positive and significant impact on innovation in renewables (Johnstone et al., 2010). The impact is higher than for feed-in tariffs but much lower than for specific R\&D policies. As expected, electricity certificate systems encourage innovations in technologies that are closest to the market (wind) as they have a quick market return while feed-in tariffs and specific R\&D spending also boost innovation in technologies that are further from the market (solar). Sweden is one of the countries with the largest number of patents on renewables over 1978-2005, which could be a sign that the electricity certificate system has been successful in promoting R\&D in this area (Figure 12).

Electricity certificate systems subsidise renewable electricity producers because the certificate value that they do not have to pay is a form of subsidy to their production (Fischer and Newel, 2007). These systems have a number of shortcomings:

- Deadweight losses are large as a majority of the certificates $\left(76 \%{ }^{10}\right)$ has been attributed to old and profitable plants that would have developed renewable electricity anyway. As it is very likely that these old plants have also benefited from other forms of governmental support (otherwise, they would not have existed), consumers have in fact paid two times the cost of the development of electricity from renewables. In order to address this problem, the government has decided that old plants (which represent $80 \%$ of the supply of certificates) should be phased out from the system in 2012 .

- Although the government has published in advance the yearly quota for 2003-30, the price of certificates has been relatively volatile (Figure 11), which is likely to have been detrimental to investment. This is partly because of low liquidity as there are a few participants on the supply and demand sides who can affect the price. There are discussions about enlarging the system to include Norway, which may increase liquidity. The exclusion of old plants in 2012 creates another source of uncertainty for the future price of certificate with risks of large increases. Therefore, the introduction of a price ceiling is under discussion. The system also 
generates some transaction costs that are estimated to represent around $6 \%$ of the price of the certificate on average (Swedish Energy Agency, 2009).

Figure 11. Average price of spot traded electricity certificates in the electricity certificate system

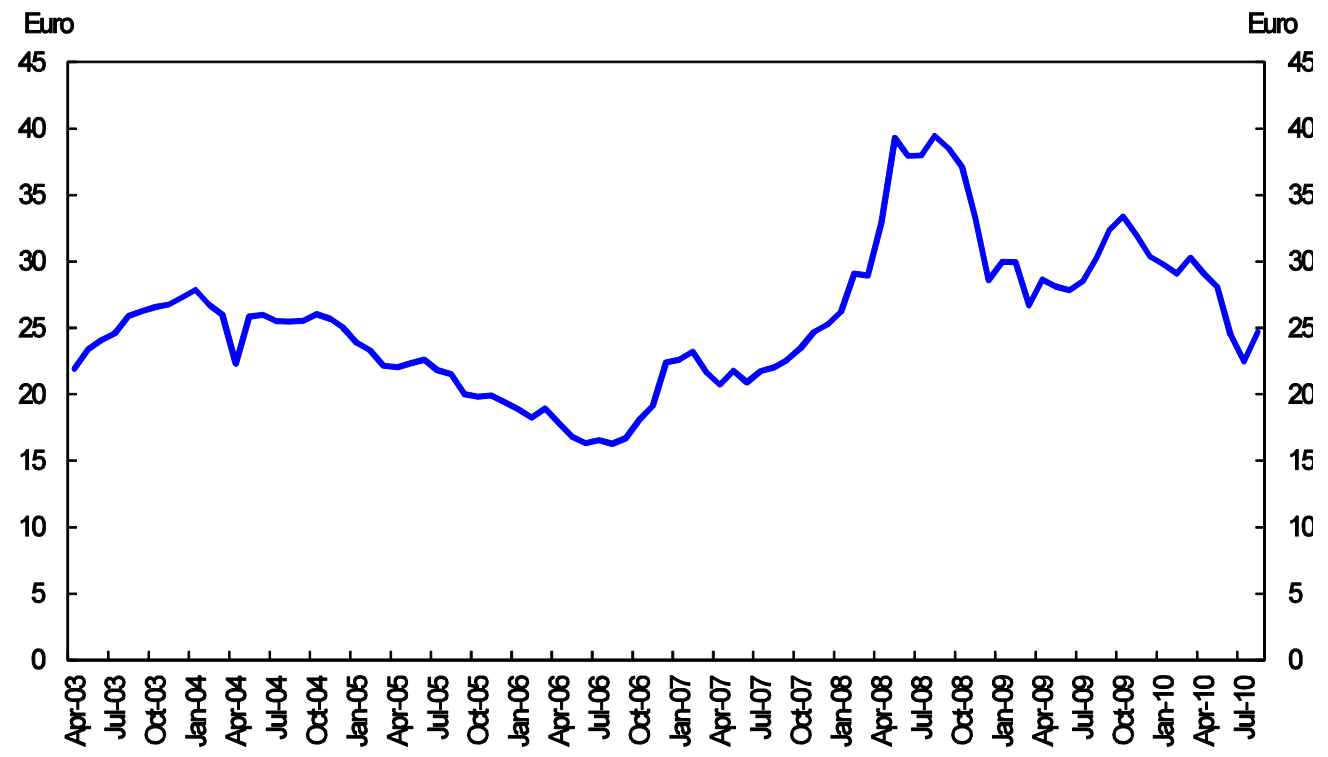

Source: SKM Tricorona.

Figure 12. Patents in renewable energy technologies1, 1978-2005

Number per unit of GDP

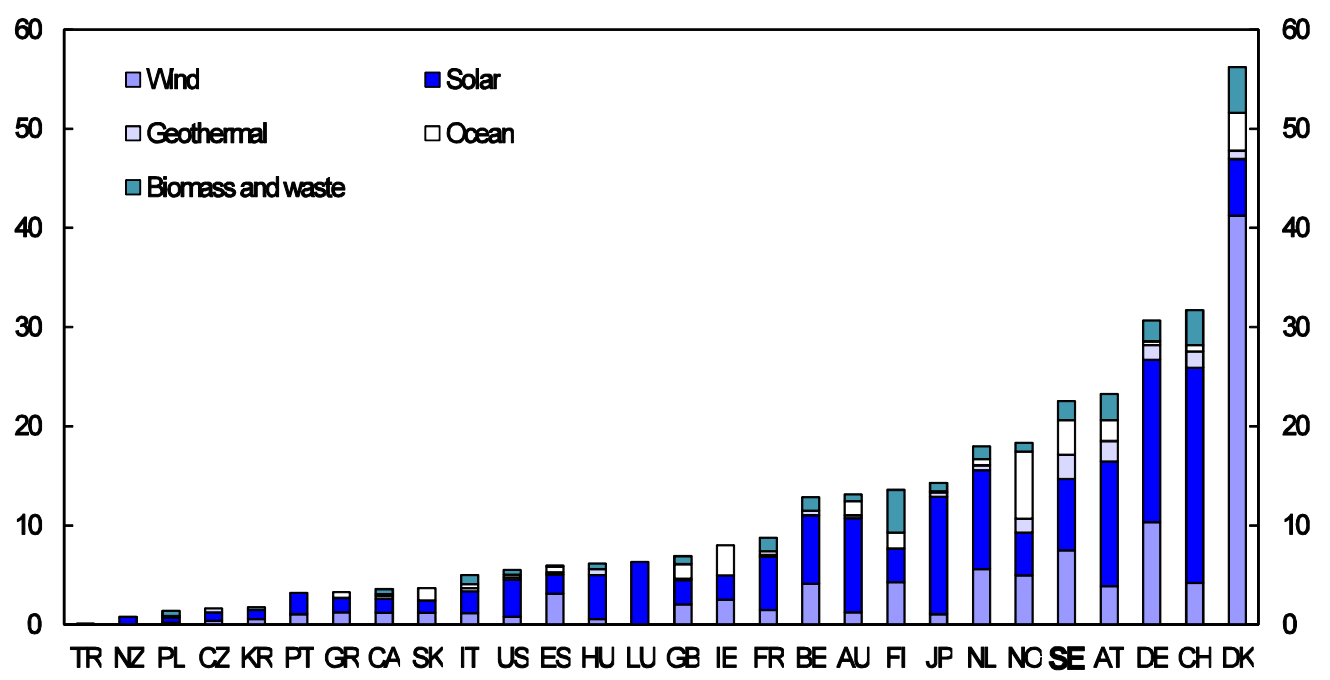

1. Data are from the European Patent Organisation (EPO). The annual mean number of patent applications for renewables during 1978-2005 normalised by GDP (in trillions of US dollars, using 2000 prices and at PPP).

Source: Johnstone et al. (2010). 


\section{Other instruments complement the framework, some of them with low cost-effectiveness}

There are also various other policies that affect GHG emissions. In general, these instruments are difficult to assess and there is no clear justification to have them on top of other instruments (Brännlund and Kriström, 2001).

Sweden aims at having a vehicle fleet that is independent of fossil fuels by 2030 and has adopted a number of technology and performance standards to achieve this goal. For instance, there is an obligation for all large filling stations to sell at least one renewable fuel and filling stations that wish to sell biogas have received subsidies. There are also several tax exemptions for "green" cars and the government has recently announced a subsidy for very low-emission cars. The main problem with these measures is their very high cost. Model simulations suggest that a carbon price of $€ 150$ per tonne of $\mathrm{CO}_{2}$ would have been needed to bring emissions in this sector back to their 1990 level by 2010 (Broberg et al., 2008). As the mix of instruments used in this sector is unlikely to be a cost-effective one since it targets specific technologies, the marginal abatement cost could be even higher. In this regard, the government's choice not to introduce a kilometre tax is welcome from a climate policy perspective, as it would have been costly and would have had a limited impact on GHG emissions. In general, the government should try as far as possible to tax GHG emissions directly at the source. Taxing cars or kilometres rather than the fuel is an indirect and imperfect way of taxing GHG emissions as these depend on how the car is used.

Sweden has encouraged the use of biofuels largely through tax incentives (biofuel being exempted from the energy and carbon taxes); investment subsidies and other measures mentioned above. The cost of reducing $\mathrm{CO}_{2}$ emissions through the development and use of biofuels depends on the type of biofuel, but can be very high, reaching $€ 350$ per tonne of $\mathrm{CO}_{2}$ (Steenblik, 2007). As Sweden is mainly importing biofuels (80\% of ethanol supply is imported, mostly from Brazil) and biofuels production is heavily subsidised in most exporting countries, the country only partly bears these costs. However, full exemptions from the energy and carbon taxes, as well as several other forms of support, are required to make the use of biofuels competitive. Such measures to encourage biofuels raise a number of problems:

- They risk creating lock-in effects as biofuels may not prove to be the cheapest way to lower emissions in the transport sector. The government has recognised this problem and is therefore now supporting a broader range of low-carbon technologies in the transport sector, including electric cars.

- The environmental impact of biofuels production depends on the type of biofuel. But in any case, when the entire production chain and transport is considered, their impact on $\mathrm{CO}_{2}$ emissions is not zero. As a large share of biofuels used in Sweden is imported from countries where the production and transport of biofuels leads to GHG emissions (such as Brazil), part of the emission reductions achieved in Sweden is arguably offset by increases elsewhere. For these reasons, biofuels should be taxed over and above VAT. The proposal by the government in the Budget Bill for 2011 to increase tax exemptions, but only for low biofuels blend in petrol and diesel, goes in the right direction but more can be done in this area. An energy tax should also be applied to biofuels. Introducing a $\mathrm{CO}_{2}$ tax on biofuels depending on their $\mathrm{CO}_{2}$ content (rather than an energy tax that taxes $\mathrm{CO}_{2}$ emissions indirectly) would give a clearer signal to consumers and would fully address the $\mathrm{CO}_{2}$ externality. However, it raises a number of difficulties and hence, could only be considered in the longer term, provided that these difficulties are overcome. Indeed, it would require calculating $\mathrm{CO}_{2}$ emissions embodied in the production and transportation processes, which is very difficult. Moreover, as fossil fuels are not taxed for the emissions generated by their production and transportation, this would lead to an asymmetry in taxation between fuels. 
Another example of an additional instrument with weak cost-effectiveness is local subsidy programmes for investments in "green" projects, of which Sweden has a long tradition. While some of these programmes have been phased out, others have replaced them, with several again targeting investment in renewable energy. With other instruments in place, there is no clear economic rationale for having these programmes on top. Furthermore, the additionality of these projects is estimated to be very low as, according to empirical estimates, $70 \%$ of them would have occurred anyway (Broberg et al., 2010). This is because municipalities receive subsidies on the basis of their application, with little check on the reference scenario. Finally the administrative costs of these projects are high, amounting to $10 \%$ of the size of the subsidy.

\section{Overall, the policy framework has lead to significant GHG emission reductions but more could have been achieved at the same cost}

According to national estimates, the policy framework has allowed GHG emissions to be reduced by $32 \%$ relative to what emissions would have been without these policies, i.e. in the "business-as-usual" scenario (Table 3). Without these policies, emissions would have increased by more than $30 \%$ over 1990-2010 instead of having decreased by 10\%. Emission reductions relative to the BAU scenario are expected to be the largest in the waste, solvents and energy sectors reflecting the drop in emissions from household energy consumption (Figure 13). They have mainly been achieved in sectors not covered by the EU ETS because energy-intensive industries, which are the main participants in the EU ETS, have benefited from tax exemptions before the introduction of the EU ETS. Since then, the EU ETS carbon price has not been durably high enough to induce substantial emission reductions.

Table 3. GHG emission reduction projections over 1990-2020 in Sweden

\begin{tabular}{|c|c|c|c|c|c|c|}
\hline Total GHG emissions (excl. LULUCF ${ }^{1}$ ) & 1990 & 2010 & 2020 & $1990-2010$ & $2010-2020$ & $1990-2020$ \\
\hline & \multicolumn{3}{|c|}{ Millions of tonnes $\mathrm{CO}_{2} \mathrm{eq}$} & \multicolumn{3}{|c|}{$\%$ change } \\
\hline Business as usual & 71.93 & 96.09 & 98.18 & 33.6 & 2.2 & 36.5 \\
\hline With current policies & 71.93 & 64.99 & 63.18 & -9.6 & -2.8 & -12.2 \\
\hline Covered by the EU ETS & 21.2 & 21.8 & 22.2 & 2.8 & 1.8 & 4.7 \\
\hline Outside the EU ETS & 50.8 & 43.2 & 40.9 & -15.0 & -5.3 & -19.5 \\
\hline $\begin{array}{l}\text { With } 2009 \text { measures and reductions } \\
\text { financed outside Sweden }\end{array}$ & 71.93 & 64 & 53.7 & -11.0 & -16.1 & -25.3 \\
\hline Covered by the EU ETS & 21.2 & 21.8 & 22.2 & 2.8 & 1.8 & 4.7 \\
\hline $\begin{array}{l}\text { Total outside the EU ETS including } \\
\text { reductions outside Sweden }\end{array}$ & 50.8 & & 31.5 & & & -38.0 \\
\hline $\begin{array}{r}\text { Of which: outside the EU ETS in } \\
\text { Sweden }\end{array}$ & 50.8 & 42.2 & 38.2 & -16.9 & -9.5 & -24.8 \\
\hline
\end{tabular}

1. Land use, land-use change and forestry.

Source: OECD calculations based on Ministry of the Environment Sweden (2009). 
Figure 13. Projected GHG emission reductions by sector, 2010

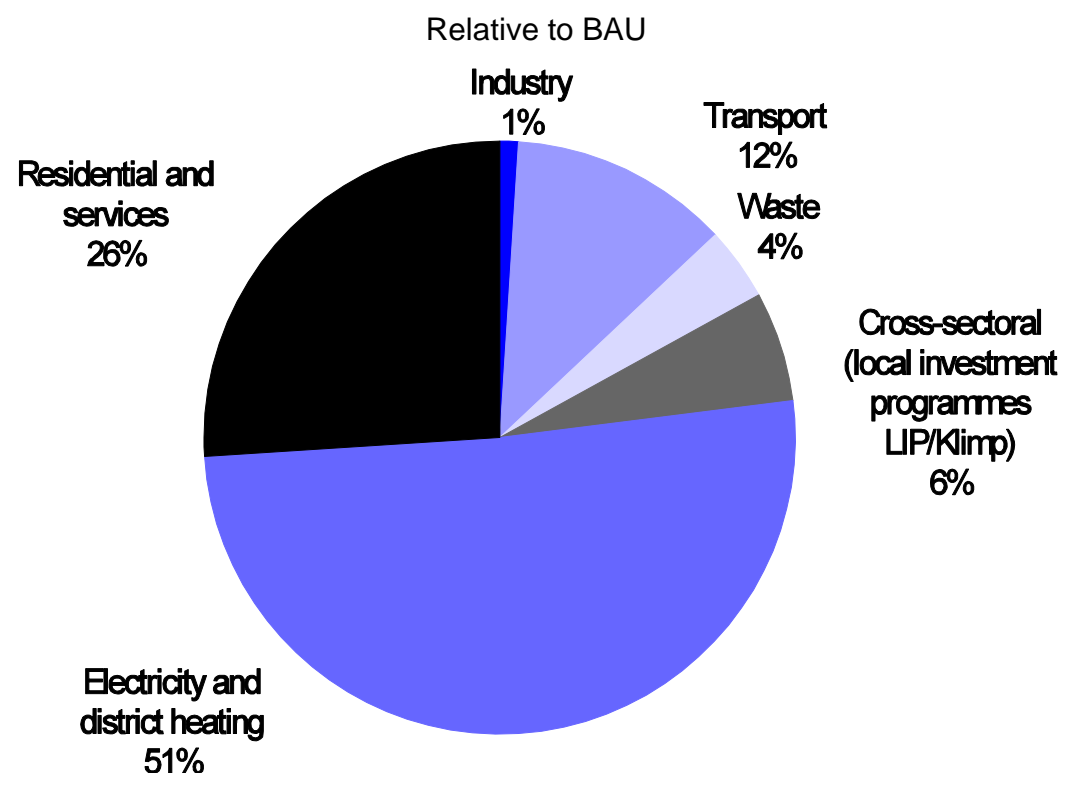

Source: Ministry of the Environment, (2009).

There is no assessment of the overall cost of these reductions. OECD model-based estimates show that a 10\% decrease in GHG emissions relative to the 1990 level (corresponding to what has been achieved in Sweden) in the EU would cost $0.2 \%$ of GDP (OECD, 2009a). However, this cost should be considered as a lower bound as this estimate assumes that the emission reductions are fully achieved through a carbon tax, while Sweden has also used some more costly instruments.

There are some national estimates of the cost of various technical measures to reduce emissions in the electricity and heating supply sectors where most emission reductions took place (Ministry of the Environment, 2009). These estimates show that the techniques that have led to the largest reductions in Sweden have also been the most costly. For instance, a carbon price of around $€ 100$ per tonne of $\mathrm{CO}_{2}$ was needed to make the switch from oil to biomass fuels in individual houses (which accounts for a large share of emission reductions in Sweden) profitable. OECD estimates show that with a carbon price of $€ 100$ per tonne of $\mathrm{CO}_{2}$ in the $\mathrm{EU}, \mathrm{GHG}$ emissions could be reduced by $30 \%$ relative to 1990 levels in the EU with a GDP cost slightly above $1 \%$. These estimates represent an upper bound on the size of emission reductions and a lower bound for their cost, as they assume full coverage of the carbon price in terms of sectors and countries. Nonetheless, they suggest that greater emission reductions could have been achieved at a similar cost with a more cost-effective policy framework.

\section{Moving forward: improving the cost-effectiveness of the policy framework}

Sweden has adopted a target to reduce GHG emissions by $40 \%{ }^{11}$ over $1990-2020$ in sectors not covered by the EU ETS (Table 2). Almost $40 \%$ of this reduction has already been achieved over 19902010 , and another $35 \%$ is expected to be achieved through the financing of emission reductions abroad. The rest will have to be achieved domestically and corresponds to a reduction by $10 \%$ in sectors outside the EU ETS over 2010-20. It is estimated that the financial and economic crisis, by reducing GDP during the crisis, has lowered GHG emissions by 1 million tonnes in sectors not covered by the EU ETS, making the target easier to achieve (National Institute of Economic Research, 2010). ${ }^{12}$ In July 2009, Parliament adopted a Climate Strategy with measures to achieve this target, notably hikes in the energy and $\mathrm{CO}_{2}$ taxes for sectors that benefit from reduced rates (see Annex 1). 
While Swedish climate change activism has been commendable, it is important for Sweden to improve the cost-effectiveness of existing and future policies so as to be able to achieve its targets at least cost. As cheap abatement opportunities in Sweden have been partly exhausted, the marginal cost of reducing emissions further could be high. Recommendations are summarised in Box 4.

\section{Making the carbon price more uniform, more visible and even more central}

A key step to improve the cost effectiveness of the policy framework is to reduce the differences in carbon prices for sectors outside the EU ETS. Progress has been achieved in this direction but more remains to be done:

- Further removing exemptions from the carbon tax, in line with Parliament's 2009 decision, coming into force in 2011, 2013 and 2015. In particular, the measures to increase the $\mathrm{CO}_{2}$ tax in industry and agriculture and to phase out reductions for energy-intensive industries that are outside the EU ETS are a useful step. NIER's estimates show that raising the minimum $\mathrm{CO}_{2}$ tax rate to $€ 30$ per tonne of $\mathrm{CO}_{2}$ would reduce emissions with negligible effects on GDP (Broberg et al., 2008).

- Clarifying the objectives of the $\mathrm{CO}_{2}$ tax and the energy tax and adjusting the tax rates accordingly, so that the $\mathrm{CO}_{2}$ tax becomes the major instrument covering the $\mathrm{CO}_{2}$ externality while the energy tax, and possibly other taxes, deal with other environmental externalities.

- Assessing any proposals to change the $\mathrm{CO}_{2}$ tax rates or energy tax rates against their impact on the heterogeneity of effective tax rates on $\mathrm{CO}_{2}$. While some proposals like the one to increase the tax on motor fuel can lead to emission reductions, they can also lead to a deterioration in the cost-effectiveness of the overall framework by increasing the disparities in effective $\mathrm{CO}_{2}$ tax rates (Broberg et al., 2008).

Standards and other legal requirements entail a shadow price for carbon and thus also contribute to differences in carbon prices. Furthermore, as the cost of adopting these regulations is at least partly unknown ex ante, they make price signals less clear. The price signal could be made more visible by limiting the use of non-market based instruments to situations where there is a distinct market failure. For instance, the Climate Committee made a recommendation that was finally not retained in the Climate Strategy, to increase the railway capacity by $50 \%$, which is a form of performance standard. The NIER's assessment showed that the cost of this proposal was the highest of all proposals, reaching $€ 500$ per tonne of $\mathrm{CO}_{2}$ eq.

\section{Raising the share of GHG emission reductions achieved in sectors covered by the EU ETS and outside Sweden}

Another step to raise the cost-effectiveness of Sweden's policy framework would be to lower the difference in carbon prices between sectors that are outside and inside the EU ETS, in order to have a uniform carbon price at the national level. The EU ETS carbon price is currently lower than the effective $\mathrm{CO}_{2}$ tax rates in most sectors outside the EU ETS and this gap is likely to widen further as a $20 \%$ emission reduction inside Sweden requires larger efforts than an EU-wide 20\% reduction, since many other EU countries have cheaper abatement opportunities. Hence, for the carbon prices to converge, three options could be considered in theory: $i$ ) lowering $\mathrm{CO}_{2}$ effective tax rates in Sweden's non-EU ETS sector; ii) raising the carbon price in EU ETS sectors; or iii) a mix of $i$ ) and ii). Measures presented above to make the carbon price more uniform (by broadening the tax base of the $\mathrm{CO}_{2}$ tax) and more central in non-EU ETS sectors would allow the effective carbon price to be lowered in these sectors for a given emission reduction target, but they are unlikely to lead to a full convergence to the EU ETS carbon price level. 
From an international perspective, cost-effectiveness requires that marginal abatement costs be equalised across countries. Assuming that the EU carbon price will increase and that a world carbon price will gradually emerge, Sweden should in fact freeze or even decrease its carbon price so as to let the EU ETS carbon price gradually converge towards it. However, this would lower the emission reductions achieved in Sweden. To maintain the level of ambition of its objectives, Sweden could offset these lower reductions by financing more emission reductions in non-Annex I countries through flexible mechanisms such as the Clean Development Mechanism (CDM). Emissions crediting mechanisms such as the CDM have the potential to provide larger and cheaper opportunities to reduce GHG emissions than the EU ETS. However, the current CDM suffers from a number of weaknesses, notably the often low additionality of projects (Wara and Viktor, 2008) and the large transaction costs that generate some bottleneck problems (OECD, 2009a). Sweden should continue to work at the international level towards improving the efficiency of flexible mechanisms so as to raise their environmental integrity and to lower their transaction costs. Sweden could also finance emission reductions outside Sweden by contributing to an international fund, provided that it meets a number of quality criteria.

Another option would be for Sweden to achieve more GHG emission reductions under the EU ETS. As explained above, as long as Sweden would continue to be a potential net seller of permits, the country will not benefit from the opportunity of lowering its mitigation cost by financing emission reductions in EU countries with lower marginal abatement costs (in Eastern Europe for instance). One option for Sweden would be, in future negotiations, to offer, for a given allocation of EU allowances between countries agreed at the EU level, to reduce its own allocation conditional on a downward adjustment of the EU level quota by the same amount. ${ }^{13}$ Another option would be for Sweden to buy permits with a strong commitment by Sweden's governments not to use them. These options would avoid that Sweden's larger contribution is offset by less ambitious efforts by other countries. As more ambitious targets would then be achieved at the EU level, the EU ETS carbon price would tend to rise,${ }^{14}$ allowing more emission reductions to be achieved in EU ETS sectors in Sweden. However, the ability for Sweden to influence the EU ETS carbon price can only be limited given the low share of its GHG emissions in the aggregate EU ones.

The option to add a $\mathrm{CO}_{2}$ tax to the EU ETS carbon price in EU ETS sectors in order to raise the carbon price in these sectors, which is in fact what the electricity certificate system is already doing, raises a number of problems. It would imply that more emission reductions would be achieved in EU ETS sectors in Sweden, lowering the demand for EU allowances from Sweden and thereby the EU ETS carbon price, leading to less emission reductions in other EU countries. So as to avoid that larger emission reductions in Sweden are offset by lower emission reductions outside Sweden, the overall EU cap would have to be adjusted downwards as explained above. However, the cost-effectiveness of the EU ETS would then be lowered as marginal abatement costs are relatively large in Sweden. It would be more cost-effective to achieve the same level of emission reductions at the EU level with less of these reductions achieved in Sweden. One argument against moving emission reductions outside Sweden is that Sweden would then lose the co-benefits of the reductions, for instance in terms of local air pollutants. However, as most of these pollutants are capped at the EU and international levels, ${ }^{15}$ their costs are already internalised and the co-benefits are expected to be low.

Finding a way to address GHG emissions from LULUCF that represent one third of Sweden's emissions excluding LULUCF could also help Sweden lower its mitigation cost. This would have to be achieved in the context of an international agreement.

\section{Avoiding overlaps between targets}

Sweden has four targets to be met by 2020: an emission reduction target, an energy efficiency target, a renewables target for the energy sector as a whole and a renewables target for the transport sector. These targets have been adopted at the EU level but Sweden had decided to be a pioneer and to develop 
renewables in the electricity and transport sectors before the adoption of the targets at the EU level. Furthermore the country tends to adopt targets that are more binding than the ones set at the EU level and to also have additional priorities. For instance, Sweden has a plan to have a vehicle fleet that is "independent" from fossil fuels by 2030.

Having several targets that have impacts on GHG emissions generates additional constraints on the economy and hence raises the cost of meeting the GHG emissions reduction target. Furthermore, it is more costly to achieve four targets than only one, especially because the targets interact together. For instance, by stimulating the production of renewable energy, the renewable energy target makes the energy efficiency target more difficult to achieve.

The renewables target may have been particularly binding for the economy. Sweden aims at having half of its energy produced from renewables. However, as the largest part of the effort has already been realised, future costs are expected to be limited. The remaining part of the effort would require developing renewables further in both the electricity and transport sectors. The government plans to achieve $10 \%$ of the increase in renewables through the electricity certificate system. The remaining part of the effort would come from the increase in the $\mathrm{CO}_{2}$ and energy taxes in the transport sector and some investment subsidies for biofuels.

Given that most renewables are not competitive with fossil fuels, the national cost of the policies that have been implemented to raise the share of renewable energy is expected to be very large. By forcing emission reductions to be realised in sectors and through specific technologies with potentially high marginal abatement costs, these policies have increased the cost of meeting the climate change target. Furthermore, as most sectors are covered by a carbon price, these policies have not lead to emission reductions in addition to those generated by the carbon prices (the EU ETS one and the energy and carbon taxes). This is particularly the case for the electricity certificate system, which has forced emission reductions to be achieved through the development of renewables in the electricity sector while they could have been achieved otherwise by other technologies with potentially lower costs.

At the EU level, the renewables target is justified as a way to decrease the EU's dependence on imported energy and the Swedish government uses the same justification. While the development of renewables may have improved Sweden's energy security, it is not obvious that there is a need for specific support to renewables in addition to that induced by the carbon price. This is particularly the case in the electricity sector, where Sweden is already a net exporter. Furthermore, the credible long-term carbon price that Sweden has successfully introduced provides a strong incentive to develop these technologies (OECD, 2009a). Even if, for technological, political or safety reasons, the uptake of nuclear energy were to be constrained, OECD model-based simulations show that incentives to invest in renewables technologies would be even more strongly stimulated by a carbon price. Policies to increase the use of renewables in the transport sectors have lead to an increase in imports of biofuels and therefore have lowered the dependency on oil exporter countries but there is still a risk that the price of biofuels rises significantly in the coming years.

The energy efficiency target also leads to additional costs for Sweden. CGE model simulations show that as the energy efficiency target is reached, $\mathrm{CO}_{2}$ reduction overshoots the emission reduction target and that it is therefore more costly to meet both targets rather than to meet the GHG target only (Broberg et al. 2010). ${ }^{16}$

Furthermore, greater energy efficiency does not necessarily lead to less GHG emissions. This is because an increase in energy efficiency has at least two effects (Brannlund et al., 2004): $i$ ) as the energy cost is lower because of the increased energy efficiency, more energy is consumed, which partly offsets the initial saving potential; $i$ ) general equilibrium effects, such as changes in aggregate consumption patterns 
that lead to structural change and changes in relative prices with effects on emissions but with an unknown sign. Model simulations from this study show that an increase in energy efficiency (in the transport sector for instance) would increase the demand for cars and for other goods and hence, would increase emissions. To keep $\mathrm{CO}_{2}$ emissions constant, the carbon tax would need to be raised significantly.

The latest OECD Economic Survey of the European Union suggested modifying the EU targets so as to make them less costly to individual countries and for the EU as a whole (OECD, 2009b). Specifically, it recommended: $i$ ) the removal of the biofuel target; ii) the harmonisation of national renewable energy support and a removal of this support once energy technologies compete fairly, i.e once all external costs and market failures other than climate change are addressed; and iii) reconsideration of the usefulness of the energy efficiency target. Acceptance of such recommendations would help Sweden lower the cost of its climate change policies.

Furthermore, although Sweden wants to be a leader in climate change policies, the country should be careful in assessing the real impact on its economy of introducing targets that are more binding than the EU ones, especially when they are not expected to lead to additional emission reductions on a global scale. In particular, as there is no economic rationale for developing a fossil-fuel independent vehicle fleet by 2030, this ambition should be given up. The government should also implement a cost-benefit analysis of the policies that have contributed to the development of renewables and should consider the phasing out of the instruments where costs exceed benefits. The same rule should apply to the electricity certificate system. Meanwhile, so as to lower the deadweight losses of this system, only technologies for which a market failure justifies supporting the technology above the effect of the EU carbon price should give rise to certificates. The government could also consider introducing a price ceiling to certificates (or relaxing the quota) so as to avoid costly technologies being developed too early in the innovation cycle. Learning-by-doing, for instance coming from R\&D in other technologies or from other countries, gradually reduces the cost of low-carbon technologies.

\section{Developing the assessment of climate change policies}

Sweden's climate change objectives are part of a set of environmental objectives, which originally comprised 15 quality objectives adopted by Parliament in 1999. Other climate change objectives have been introduced since, including those of the 2009 Climate Strategy. In 2009, the government launched an inquiry to assess the environmental objectives system (Swedish Government Inquiries, 2009). The report includes a number of criticisms and proposals, some of which are discussed below, that if implemented would largely improve the institutional framework for climate change policies.

A major weakness of the climate change policy framework is the insufficient assessment of policies. Policies are reviewed but there are few quantitative assessments of the impacts on both emissions and welfare. Furthermore, the assessments often concern some specific sectors and are done only occasionally. There is little analysis of the objectives and of their global implications, both ex post and ex ante.

As pointed out by the inquiry, this is partly because, while there are several institutions involved in climate change policies, their responsibilities are not fully defined. The Ministry of the Environment is in charge of deciding climate change objectives and policy instruments and is responsible for EU and global climate negotiations. The Swedish Environmental Protection Agency (SEPA), created in 1967, is a national agency whose task is to present proposals for environmental policy and legislation to the Swedish Government and to ensure that environmental policy decisions are implemented. The Swedish Energy Agency (SEA) is a government agency for national energy policy issues. Its mission is to promote the development of Sweden's energy system so that it will become ecologically and economically sustainable. Hence, these three institutions are implicitly in charge of assessing climate change policies but none of them has received a clear mandate to do so both regularly and by covering the whole range of effects. 
Recently, the National Institute of Economic Research has developed resources and tools and, in particular, it has assessed the Parliamentary Climate Committee's proposals for the 2009 Climate Strategy. Several of the NIER's criticisms led to changes to the strategy. This form of assessment should be made more systematic. The government should also develop independent policy assessments.

Another weakness of environmental policies, in particular climate change policies, that was raised by the Swedish Government Inquiries (2009) is that objectives are not seen in an international context and that the interactions between Sweden's national objectives and international ones should be more carefully analysed. This is typically true for climate change policies that have been only marginally adapted to the introduction of the EU ETS. The main decision that has been taken was to exempt industries covered by the EU ETS from the carbon tax while Sweden should in fact reconsider its policies in the light of the development of EU-wide actions. Developing policy evaluations by both governmental agencies and independent ones would also help in this respect.

\section{Box 4. Summary of recommendations to enhance the cost-effectiveness of climate change policies in Sweden}

\section{Make the carbon price more uniform and raise the clarity of the price signal}

Continue to gradually phase out exemptions to the carbon tax and avoid introducing measures that would increase the heterogeneity of effective $\mathrm{CO}_{2}$ tax rates. Consider freezing or lowering the general level of the $\mathrm{CO}_{2}$ tax while enlarging the tax base if it is consistent with national GHG emission reduction targets.

Limit the interactions between the carbon tax and the energy tax by reforming the two. As far as possible, address the carbon dioxide externality only through the carbon tax. Use the energy tax and perhaps other taxes to address other externalities.

Tax biofuels over and above VAT to account for GHG emissions, partly outside Sweden, generated by the production and imports of biofuels. This can be done, as is planned by the government, by assessing tax exemptions against environmental sustainability criteria. Moreover, an energy tax should be applied to biofuels.

Limit the use of other instruments that implicitly generate a carbon price to situations where there is a distinct market failure or a clear other reason for having them. As the electricity certificate system is in place, phase out other forms of support to renewables in the electricity sector. Phase out most subsidies to local public investments in green technologies that have delivered limited GHG emission reductions. Sweden

Raise the share of GHG emission reductions achieved in sectors covered by the EU ETS and outside

In future negotiations on the allocation of permits within the EU ETS, take a larger share of the effort by negotiating lower permit allocations conditional on a downward adjustment of the EU level quota or by buying EU ETS permits with a strong commitment not to sell them in the future.

Work at the international level to reform existing flexible mechanisms so as to limit their additionality and bottleneck problems.

\section{Avoid the overlap of targets}

Assess the costs and gains of having developed renewable energy and of developing it even further. If renewables targets are renegotiated at the EU level, consider negotiating less binding national targets.

Restrict access to the electricity certificate system to technologies that require support in addition to that provided by the EU ETS carbon price. Introduce some provisions to avoid the certificate price reaching levels that generate excessively large costs to consumers. One possibility is to relax the quotas, another one is to introduce a price ceiling.

In the transport sector, avoid measures that target the development of one specific technology. 
Reconsider the fossil-fuel-independent vehicle fleet ambition.

\section{Improve the assessment of climate change policies}

Develop ex ante and ex post evaluations by both governmental and independent institutions of the global effects of climate change policies.

Clarify the responsibilities between governmental institutions that are involved in climate change policies and put one of them in charge of the overall assessment of policies.

Assess more carefully the interactions between Sweden's climate change policies and those decided at an international level.

\section{Notes}

1. Annex I countries that have ratified the Kyoto protocol include the industrialised countries that were members of the OECD in 1992, plus countries with economies in transition, including the Russian Federation, the Baltic States, and several Central and Eastern European States.

2. There is another channel, the fossil fuel price channel, according to which emission reduction efforts in participating countries lower world demand for fossil fuels, thereby inducing a price decline that triggers greater fossil fuel use and higher GHG emissions in non-participating countries. This channel is predominant for large coalitions but not when a small country acts alone.

3. On the one hand, this estimate does not take into account exemptions that lower the impact on emissions. On the other hand, it does not include the impact of the energy tax on GHG emissions. Furthermore, the extrapolation assumes a linear relationship between the $\mathrm{CO}_{2}$ tax and emission reductions.

4. The EU scheme will be extended to emissions from aviation from 2012 and to emissions from aluminium and chemical industries from 2013.

5. When allowances are auctioned, they simply do not buy allowances, or buy fewer.

6. In the absence of market imperfections, all countries would gain from trading: permit sellers would benefit from additional revenues while permit buyers would lower their mitigation cost.

7. Each year, companies submit an annual declaration of the amount of electricity sold or used during the previous year, which provides the basis for the calculation of companies' quota obligations. There is a penalty to be paid if the number of certificates does not cover the quota obligation, which has been revised up to $150 \%$ of the yearly average price of certificates.

8. From 2003 to 2005, the number of certificates issued exceeded the demand for them.

9. See Fisher and Newel (2007), Bye and Bruvoll (2008) and Bye and Bruvoll (2009) for recent critiques of Norway's green certificate system that shares several similarities with the Swedish system.

10. The figure was quoted in: http://svt.se/2.131518/1.1989708/miljonbidrag_till_gamla_kraftverk.

11. It represents a reduction by 20 millions of tonnes of $\mathrm{CO}_{2}$ eq.

12. GHG emissions will have to decrease by $7 \%$ in these sectors compared to a reduction by $10 \%$ before the crisis. 
13. Broberg et al. (2008) show that stricter allowances allocation under the EU ETS would lower the cost of achieving the national target.

14. For other countries, the cost of the slight increase in the carbon price would be offset by financial transfers from Sweden.

15. The National Emission Ceilings Directive imposes emission ceilings for emissions of four key air pollutants (nitrogen oxides, sulphur dioxide, non-methane volatile organic compounds and ammonia). Other key EU legislation is targeted at reducing emissions of air pollutants from specific sources, including transport and industrial facilities. Internationally, the issue of air pollution emissions is also being addressed by the Convention on Long-range Transboundary Air Pollution.

16. To reduce GHG emissions by $40 \%$ in sectors not covered by the EU ETS, with one third of the reduction being achieved outside Sweden, the general level of the $\mathrm{CO}_{2}$ tax has to be increased from $€ 100$ to $€ 180$ per tonne of $\mathrm{CO}_{2}$ eq. To reach the energy efficiency target, the $\mathrm{CO}_{2}$ tax has to be raised to $€ 220$ per tonne of $\mathrm{CO}_{2}$ eq., costing an additional $0.1 \%$ of GDP. 


\section{Bibliography}

ADEME (2009), "Fiscalité comparée de l'énergie et du CO2 en Europe et en France", Stratégie et Études No. 20.

Andersen, M. (2004), "Vikings and Virtues: A Decade of CO2 Taxation", Climate Policy, Vol. 4, No. 1, pp. 13-24.

Barker, T, S. Junankar, H. Pollitt and P. Summerton (2007), "Carbon Leakage from Unilateral Environmental Tax Reforms in Europe, 1995-2005”, Energy Policy, Vol. 35, pp. 6281-6292.

Bollen, J., B. Guay, S. Jamet and J. Corfee-Morlot (2009), "Co-benefits of Climate change Mitigation Policies: Literature Review and New Results", OECD Economics Department Working Papers, No. 692.

Brännlund, R., T. Lundgren and P.-O. Marklund (2010), "Environmental Performance in Swedish Industry", mimeo, Umeå University, Sweden.

Brännlund, R., T. Ghalwash, and J. Nordström (2004), "Increased Energy Efficiency and the Rebound Effect: Effects on Consumption and Emissions", No. 642, Umeå Economic Studies, Umeå University, Department of Economics, http://econpapers.repec.org/RePEc:hhs:umnees:0642.

Brännlund, R. and Kriström, B. (2001), "Too Hot to Handle? Benefits and Costs of Stimulating the Use of Biofuels in the Swedish Heating Sector", Resource and Energy Economics, Vol. 23, No. 4, pp.343-58.

Broberg T., Samakovlis E., and J. Forslund (2010), "Investeringsstöd - ett överskattat styrmedel i miljöpolitiken”, Ekonomisk Debatt, Nr 3.

Broberg, T., E. Samakovlis, M. Sjöström and G. Östblom (2008), "Economic Assessment of the Climate Committee's Action Plan for Swedish Climate Policy", Specialstudier No. 18, National Institute of Economic Research.

Broberg, T., T. Forsfält, G. Östblom (2010), "Integrerade mål inom klimat- och energipolitiken”, Forthcoming report, Expert group for Environmental studies.

Duval, R. (2008), “A Taxonomy of Instruments to Reduce Greenhouse Gas Emissions and Their Interactions", OECD Economics Department Working Papers, No. 636.

Bye, T. and A. Bruvoll, (2009) "Green Certificates and the Effect on the Climate", http://www.ssb.no/english/research/articles/2009/12/1259932098.4.html, English translation of "Grønne sertifikater- dyr og formålsløs fornybar", Samfunnsokonomen, No. 7.

Bye, T. and A. Bruvoll, (2008), "Multiple instruments to change energy behaviour: The emperor's new clothes?", Discussion Papers 549, Research Department of Statistics Norway. 
Fischer, C. and R. Newell (2007), "Environmental and Technology Policies for Climate Mitigation", Journal of Environmental Economics and Management, Vol. 55, No. 2.

Hassett, K., A. Mathur and G. Metcalf (2008), "The Incidence of a U.S. Carbon Tax: A Lifetime and Regional Analysis”, NBER Working Papers, No. 13554.

Hill, M. and B. Kriström (2002), "Sectoral EU-Trading and other Climate Policy Options: Impacts on the Swedish Economy”, mimeo Skogsekonomi, SLU.

IEA (2009a), Emissions of $\mathrm{CO}_{2}, \mathrm{CH}_{4}, \mathrm{~N}_{2} \mathrm{O}, \mathrm{HFC}, \mathrm{PFC}$ and $\mathrm{SF}_{6}$, IEA, Paris

IEA(2009b), Emissions from Fuel Combustion, IEA, Paris.

IEA (2010a), World: Energy statistics and Balances, IEA, Paris.

IEA (2010b), Renewables Balance, IEA, Paris.

Jamet S. and J. Corfee-Morlot (2009), “Assessing the Impacts of Climate Change: A Literature Review”, OECD Economics Department Working Papers, No. 693.

Johansson, B. (2000), "The Carbon Tax in Sweden”, in Innovation and the Environment, OECD, Paris.

Johnstone, N., I. Hascic and D. Popp (2009), "Renewable Energy Policy and Technological Innovation: Evidence Based on Patent Counts", Environmental \& Resource Economics, Vol. 45(1), pp 133-155.

Ministry of Finance (2009), Effektivare skatter på klimat- och energiområdet, DS 2009:24.

Ministry of the Environment (2009a), Sweden's Fifth National Communication on Climate Change, Ds 2009:63.

Ministry of the Environment (2009b), A Sustainable Energy and Climate Policy for the Environment, Competitiveness and Long-Term Stability, Stockholm.

National Institute of Economic Research (2010), Konjunkturläget, September.

OECD (2006), The Political Economy of Environmentally Related Taxes, Paris.

OECD (2008), Environmental Outlook to 2030, OECD, Paris.

OECD (2009a), The Economics of Climate Change Mitigation: Policies and Options for Global Action beyond 2012, OECD, Paris.

OECD (2009b), OECD Economic Survey: European Union, OECD, Paris.

OECD (2010a), "Costs and Effectiveness of the Copenhagen Pledges: Assessing Global Greenhouse Gas Emissions Targets and Actions for 2020", OECD, Paris.

OECD (2010b), Economic Outlook No. 87, OECD, Paris.

Poterba, J. (1991) “Tax Policy to Combat Global Warming: On Designing a Carbon Tax", in R. Dornbusch and J. Poterba (eds.), Global Warming: Economic Policy Responses to Global Warming, pp. 71-98, MIT Press, Cambridge, MA. 
ECO/WKP(2011)10

Steenblik, R. (2007), "Subsidies: The Distorted Economics of Biofuels”, in Biofuels: Linking Support to Performance, OECD/ITF, Paris.

Stern, N. (2007), The Economics of Climate Change: The Stern Review, Cambridge University Press, Cambridge.

Swedish Government Inquiries (1997), Skatter, Miljö och Sysselsättning, SOU 1997:11.

Swedish Government Inquiries (2009), Sweden's Environmental Objectives - New Perspectives, SOU 2009:83.

Swedish Energy Agency (2008), The Electricity Certificate System.

Tol, R. (2005), "The Marginal Damage Costs of Carbon Dioxide Emissions: an Assessment of the Uncertainties", Energy Policy, Vol. 33, pp. 2064-2084.

Wara, W. and D. Victor (2008), “A Realistic Policy on International Carbon Offsets”, Working Paper No. 74, Stanford University. 
ECO/WKP(2011)10

\section{ANNEX 1. SWEDISH CLIMATE AND ENERGY POLICIES}

The Swedish policy framework to mitigate GHG emissions includes a large number of policies.

\section{Taxes}

A carbon tax was introduced in 1991. An energy tax also taxes fossil fuels with a tax rate that depends on fuels but not directly on their $\mathrm{CO}_{2}$ content. The general level of the carbon tax has been progressively increased and has now reached $€ 111$ per tonne of $\mathrm{CO}_{2}$. Manufacturing industry, agriculture, forestry and aquaculture pay $21 \%$ of the general level of the tax and there are special rules for further tax reductions for energy-intensive industries and for diesel used in land-based industries. Biofuels are exempted from the energy and carbon taxes. Looking ahead, the Swedish Parliament decided in December 2009 to gradually increase the general carbon tax and to reduce these exemptions, including:

- The carbon tax on fossil fuels for heating in industries not included in the emissions trading scheme and for agriculture, forestry and aquaculture activities will be increased from $21 \%$ to $60 \%$ of the general level by 2015, with a first move to $30 \%$ by 2011 .

- The special reduction rules for energy-intensive companies will be gradually phased out over the period 2010-15.

- For industries included in the EU emissions trading scheme, the carbon tax will be phased out by 2011 to avoid double regulation.

- Starting in 2011, the exemptions from the carbon tax on diesel used in land-based industries will be reduced.

\section{Policies for the development of renewable energy}

The main policies for meeting the target of increasing the share of renewable energy to $50 \%$ of energy consumption by 2020 include:

- Improving and setting more ambitious targets for the electricity certificate system.

- Establishment of a national planning framework for windpower with a corresponding production capacity of $30 \mathrm{TWh}$, with $20 \mathrm{TWh}$ on land and $10 \mathrm{TWh}$ offshore.

- Improvement in the conditions for connecting up renewable electricity production to the national grid.

- Stimulation package to promote the development of vehicle biogas.

- Use of the EU Rural Development Programme (2007-13) to support and improve the production and processing of renewable energy.

- The government has announced new investments in renewable energy technologies in the Budget Bill for 2011. 


\section{Action plan for a fossil-fuel-independent vehicle fleet}

A number of policies (market-based and non market-based) aim, directly or indirectly, at reducing GHG emissions in the transport sector. The carbon and energy taxes are the main instruments. However, the rise in the carbon tax has been partially offset by the decrease in the energy tax. Other policies include:

- The obligation for all large filling stations to sell at least one renewable fuel. Filling stations that wish to sell biogas have received extra investment support.

- Support to research efforts in vehicle technology (SEK 450 million a year for the next five years) focusing on the development of electric and hybrid vehicle technology.

- An exemption from vehicle tax for the first five years for new green cars. This has replaced a green car rebate of SEK 10000 granted on the new purchase of an eco-classified car between 2007 and 2009.

- Local benefits for eco-classified cars (exemption from the congestion tax in Stockholm, free parking in some cities).

The target is for Sweden to have a vehicle fleet that is independent of fossil fuels by 2030. In addition to the measures mentioned above, the action plan includes:

- The production of transport biofuels and other liquid biofuels must fulfil certain sustainability criteria. Biofuels that generate reductions in greenhouse gas emissions of less than $35 \%$, compared to the oil alternative, may not be credited towards the target.

- Increased amount of low-blend biofuels in petrol and diesel through rapid implementation of the new EU Fuel Quality Directive. This directive provides scope for blending up to $10 \%$ ethanol in petrol and $7 \%$ biodiesel.

- Analysis of the conditions for and consequences of a quota requirement system to accelerate the introduction of renewable fuel in the transport sector.

- The government has announced in the Budget Bill for 2011 a subsidy for low-emission cars.

\section{Policies to increase energy efficiency}

Energy efficiency is stimulated by most of the general instruments, in particular by the carbon and energy taxes. There is a programme for energy efficiency in energy-intensive industry. Companies that participate in the programme receive tax relief for the energy tax on electricity. In exchange, companies have to review the potential to take measures that improve the efficiency of energy use and then to implement measures to exploit this potential. Participating companies account for one fifth of Sweden's total energy use. There are also a number of requirements for energy use in buildings as well as a requirement for energy declarations for buildings based on the EU Directive 2002/91/EC.

Going forward, specific policies that are proposed to increase energy efficiency are:

- Strengthening of regional and local energy and climate efforts. There is scope for municipalities and county councils to enter agreements on energy efficiency with the Swedish Energy Agency.

- Strengthened information and guidance initiatives.

- Support for enterprises that use significant amounts of energy - an "energy audit cheque" to help them carry out energy audits in 2010-14. 
- Strengthening of efforts in the fields of technology procurement and the launching of energy-efficient technology aimed at increasing the range of energy-efficient products on the market.

- New requirements for "smart electricity and hot water metering" in newly constructed and renovated buildings. 
ECO/WKP(2011)10

\section{WORKING PAPERS}

The full series of Economics Department Working Papers can be consulted at www.oecd.org/eco/workingpapers/

840. Policies towards a sustainable use of water in Spain (January 2011) by Andrés Fuentes

839. Increasing public sector efficiency in Slovakia (January 2011) by Felix Hüfner

838. Raising education outcomes in Switzerland (January 2011) by Andrés Fuentes

837. The Price Responsiveness of Housing Supply in OECD Countries (January 2011) by Aida Caldera Sánchez and Åsa Johansson

836. Housing markets and structural policies in OECD countries (January 2011) by Dan Andrews, Aida Caldera Sánchez and Åsa Johansson

835. Raising potential growth after the crisis: A quantitative assessment of the potential gains from various structural reforms in the OECD area and beyond (January 2011) by Romain Bouis and Romain Duval

834. The GDP impact of reform: a simple simulation framework (January 2011) by Sebastian Barnes, Romain Bouis, Philippe Briard, Sean Dougherty and Mehmet Eris

833. Improving the flexibility of the Dutch housing market to enhance labour mobility (January 2011) by Jens Høj

832. Making the Dutch pension system less vulnerable to financial crises (January 2011) by Jens Høj

831. Real house prices in OECD countries: the role of demand shocks and structural policy factors

(December 2010) by Dan Andrews

830. International financial integration and the external positions of euro area countries (December 2010) by Philip R. Lane

829. Improving fiscal performance through fiscal councils (December 2010) by Robert Hagemann

828. Minimising risks from imbalances in European banking (December 2010) by Sebastian Barnes, Philip Lane and Artur Radziwill 
827. Resolving and avoiding unsustainable imbalances (December 2010) by Sebastian Barnes

826. Current account imbalances in the euro area: a comparative perspective (December 2010) by Sebastian Barnes, Jeremy Lawson and Artur Radziwill

825. Does fiscal decentralisation strengthen social capital? Cross-country evidence and the experiences of Brazil and Indonesia

(December 2010) by Luiz de Mello

824. Fiscal decentralisation and public investment: The experience of Latin America (December 2010) by Luiz de Mello

823. Product market regulation and competition in China

(December 2010) by Paul Conway, Richard Herd, Thomas Chalaux, Ping He and Jianxun Yu

822. Reforming China's monetary policy framework to meet domestic objectives (December 2010) by Paul Conway, Richard Herd and Thomas Chalaux

821. Regulatory reforms to unlock long-term growth in Turkey (December 2010) by Rauf Gönenç and Łukasz Rawdanowicz

820. After the crisis: mitigating risks of macroeconomic instability in Turkey (December 2010) by Lukasz Rawdanowicz

819. The 2008-09 crisis in Turkey: performance, policy responses and challenges for sustaining the recovery

(December 2010) by Łukasz Rawdanowicz

818. Fiscal-consolidation strategies for Canadian governments (November 2010) by Yvan Guillemette

817. The land transport sector: policy and performance (November 2010) by Jan Persson and Daeho Song

816. A simple model of the relationship between productivity, saving and the current account (November 2010) by Jean-Marc Fournier, Isabell Koske

815. The impact of structural policies on saving, investment and current accounts (November 2010) by Clovis Kerdrain, Isabell Koske, Isabelle Wanner

814. Towards a less distortive and more efficient tax system in Portugal (November 2010) by Alvaro Pina

813. Are global imbalances sustainable? Shedding further light on the causes of current account reversals

(November 2010) by Luiz de Mello, Pier Carlo Padoan, Linda Rousová 